\title{
Tracking "Organic" Agricultural Research in the United States, 1970-1989: What Federal Legislative and Selected USDA-Sponsored Documents Reveal
}

\author{
Leslie M. Delserone \\ Charles D. Bernholz
}

\begin{abstract}
This paper enumerates Federal government documentation of the period 1970-1989 pertaining to organic agriculture in the United States, identified in the Congressional Information Service's Cumulative Indices and bibliographies published by the United States National Agricultural Library. These Congressional hearings, Federal legislation, and selected U.S. Department of Agriculture (USDA)-sponsored documents provide an historical context for the 1990 legislation that created the National Organic Program (NOP) and the National Organic Standards Board (NOSB). The paper provides chronological tabulations of the historical documents and discusses the communication difficulties and relationships revealed therein between the Congress, the USDA, and organic producers of the time. doi:10.1300/J108v08n01_06 [Article copies available for a fee from The Haworth Document Delivery Service: 1-800-HAWORTH. E-mail address: <docdelivery@haworthpress.com> Website: <http://www.HaworthPress.com> () 2007 by The Haworth Press, Inc. All rights reserved.]
\end{abstract}

Leslie M. Delserone is Science and Engineering Librarian, University of Minnesota, 335 Walter Library, Minneapolis, MN 55455 (E-mail: delse001@umn.edu). Charles D. Bernholz is Government Documents Librarian, University Libraries, University of Nebraska, Lincoln, NE (E-mail: cbernholz2@unl.edu).

The authors gratefully acknowledge the assistance of Mary Gold, Alternative Farming Systems Information Center (National Agricultural Library) and the Interlibrary Loan staffs of the University of Nebraska-Lincoln and the University of CaliforniaSanta Cruz.

\author{
Journal of Agricultural \& Food Information, Vol. 8(1) 2007 \\ Available online at http://jafi.haworthpress.com \\ (C) 2007 by The Haworth Press, Inc. All rights reserved. \\ doi:10.1300/J108v08n01_06
}


KEYWORDS. Organic production, organic farming, alternative agriculture, sustainable agriculture, alternative farming, legislation, United States Department of Agriculture, Land Grant institutions

\section{INTRODUCTION}

On December 2, 2004, President George W. Bush nominated Governor Mike Johanns of Nebraska as Secretary of Agriculture to replace outgoing Secretary Ann Veneman. ${ }^{1}$ On both sides of the aisle, congressional representatives applauded Bush's selection; ${ }^{2}$ there was acknowledgment of the Governor's broad understanding of agricultural matters. The Johanns confirmation hearing on January 6, 2005 went smoothly, ${ }^{3}$ but for one slight wrinkle. Senator Patrick Leahy (D-Vt.) asked eight questions that Johanns declined to answer during the hearing, ${ }^{4}$ preferring instead to make written responses, ${ }^{5}$ which were received on January 19, 2005. All of Leahy's questions related to the U.S. Department of Agriculture's (USDA) National Organic Program (NOP) and/or to the National Organic Standards Board (NOSB).

Based on the most recent analysis available from the USDA's Economic Research Service (ERS), four-tenths of $1 \%$ of cropland and one-tenth of $1 \%$ of pasture in the United States met USDA organic certification standards in $2003 .{ }^{6}$ This relatively small proportion contrasts with the prevalence of organic consumerism. During the period 1991-2001, sales of organic food increased more than $20 \%$ yearly, ${ }^{7}$ equivalent to 1 to $2 \%$ of the national food market. ${ }^{8}$ In 2003, according to USDA-ERS, sales of U.S. organic food products totaled $\$ 10$ billion $^{9}$ of the nation's total food sales of more than $\$ 1$ trillion. ${ }^{10}$ As of 2002 , this potential market was "the fastest growing sector of America's agricultural economy," according to the USDA's National Program Leader for Integrated Farming Systems. ${ }^{11}$ It is not surprising, therefore, that at least one organic consumer group expressed discomfort with the incoming Secretary's "tepid support"12 for organic farming, the NOP, and the NOSB. Even given the enthusiasm of a major organic trade group for Johanns' responses to Leahy's questions, ${ }^{13}$ these written answers seemed to betray a lack of understanding of the concerns of U.S. organic farmers, little recognition of the financial impact of the organic consumer on the U.S. agricultural economy, and possibly signaled a continuation of the USDA's ambivalent relationship with the organic movement.

This article initiates a series of notes that will examine aspects of U.S. organic agriculture. For the purposes of this discussion, the phrases 
“organic agriculture," "organic farming," and "organic production" are used interchangeably. As a basis for understanding the development of the NOP and the NOSB, it is necessary to grasp some of the history of organic farming in the United States. Of particular interest is the relationship of the organic production movement with the U.S. Congress and the USDA, the leaders in monetary appropriations and in the generation of applicable research information. The selected period of 1970 through 1989 is one during which organic producers and consumers, and conventional agriculture and its proponents, intersected in a noisy and ongoing conflict. It is also the time frame immediately preceding the legislative and regulatory activities that resulted in the establishment of the NOP and the NOSB. Historical overviews of this period mention the best-known federal legislation and USDA documentation. ${ }^{14}$ While there are extensive literature searches about organic farming, the authors attempt to provide a detailed chronological listing and an evaluation, within the context of politics and the scientific attitudes of the time, of congressional hearings, legislation, and selected USDAsponsored documents. ${ }^{15}$

While not a review of the research literature pertaining to organic agriculture, this examination enumerates:

- specific government documents produced by congressional hearings, or USDA documents produced by congressional directives, and

- other scholarly publications and reports that are referenced or mentioned within the federal government information.

The bibliography in particular supports two lines of discovery:

- the impact of terminology and definitions on the identification and the retrieval processes of information relevant to organic farming, and

- an evaluation, in the discovered information, of the attitudes of members of Congress and of USDA administrators and researchers.

\section{DEFINITIONS}

First, there is the matter of an operational definition for "organic food" and "organic farming." While this discussion does not consider 
"organic gardening" specifically, there are a few exceptions found in the bibliography of Table 2, in which a hearing or document addresses both organic farming and gardening. Margaret C. Merrill makes a strong case for the cessation of the use of the term "organic" in reference to agricultural practice, suggesting instead adoption of the term "eco-agriculture." 16 However, for many producers, "organic" is an adequate or preferred description of their practices, and the emphasis is on this adjective throughout the remaining discussion. The meaning of "organic," during the years under review, depends greatly on the source. According to the NOP's current definition, "organic food"

is produced by farmers who emphasize the use of renewable resources and the conservation of soil and water to enhance environmental quality for future generations. Organic meat, poultry, eggs, and dairy products come from animals that are given no antibiotics or growth hormones. Organic food is produced without using most conventional pesticides; fertilizers made with synthetic ingredients or sewage sludge; bioengineering; or ionizing radiation. Before a product can be labeled "organic," a Government-approved certifier inspects the farm where the food is grown to make sure the farmer is following all the rules necessary to meet USDA organic standards. Companies that handle or process organic food before it gets to your local supermarket or restaurant must be certified, too. ${ }^{17}$

The NOP is part of the USDA's Agricultural Marketing Service. However, a current official working definition for "organic farming"other than that presented in this article-from the research arm of the USDA, the Agricultural Research Service (ARS), is unavailable for reasons rooted in the events of the 1970s and 1980s discussed later. To put the lack of an absolute agricultural definition for "organic" into an information context, the Congressional Information Service's (CIS) Cumulative Index for 1970-1974 (Table 1) does not index "organic agriculture" or "organic farming," or any of the frequently used synonyms "alternative agriculture," "biological agriculture," or "sustainable agriculture." 18 Within the USDA-ARS, and the other USDA branches of Science and Education and the Cooperative State Research Service, "organic" as applied to agriculture had no clear scientific definition between 1970 and 1980. In addition, a review of the documentation listed in Table 1 reveals that early legislative discussions did not use the term 
TABLE 1. Chronological Listing of Early Documentation Published Between 1970 and 1974, Reviewed for Evidence of a Specific Discussion or Consideration of Organic Agriculture

\begin{tabular}{|c|c|c|c|}
\hline Year* & Source & $\begin{array}{l}\text { Title } \\
\text { Activity } \\
\text { Subcommittee/Committee } \\
\text { Hearing Date(s) (Year Published, If Different) } \\
\text { SuDoc Number }\end{array}$ & Congress \\
\hline 1969 & Senate & $\begin{array}{l}\text { Migrant and Seasonal Farmworker Powerlessness } \\
\text { Hearings on Pesticides and the Farmworker } \\
\text { Subcommittee on Migratory Labor. Committee on Labor } \\
\quad \text { and Public Welfare. } \\
\text { Aug. } 1 \text { (1970) } \\
\text { Y4.L11/2:M58/8/pt.6-A } \\
\text { - "The Insecticide Crisis," by Robert van den Bosch, } \\
\text { Dept. of Entomology and Parasitology, University } \\
\text { of California, Berkeley (pp. 3239-3249) }\end{array}$ & $\begin{array}{l}\text { 91st, 1st, and } \\
\text { 2nd }\end{array}$ \\
\hline 1969 & Senate & $\begin{array}{l}\text { Migrant and Seasonal Farmworker Powerlessness } \\
\text { Hearings on Pesticides and the Farmworker } \\
\text { Subcommittee on Migratory Labor. Committee on Labor } \\
\text { and Public Welfare. } \\
\text { Sept. } 29 \text { (1970) } \\
\text { Y4.L11/2:M58/8/pt.6-B } \\
\text { - Excerpt from "The New Masked Man in Agriculture," } \\
\text { by Mary K. Farinholt, National Consumers Committee } \\
\text { for Research and Education (pp. 3519-3521) }\end{array}$ & $\begin{array}{l}\text { 91st, 1st and } \\
\text { 2nd }\end{array}$ \\
\hline 1969 & Senate & $\begin{array}{l}\text { Migrant and Seasonal Farmworker Powerlessness } \\
\text { Hearings on Pesticides and the Farmworker } \\
\text { Subcommittee on Migratory Labor. Committee on Labor } \\
\quad \text { and Public Welfare. } \\
\text { Sept. } 30 \text { (1970) } \\
\text { Y4.L11/2:M58/8/pt.6-C } \\
\text { - Excerpt from "Memorandum on Pesticides," by } \\
\text { Environmental Clearinghouse, Inc. (pp. 3897-3898) } \\
\text { - Excerpt from "Pesticide Pollution. Part II. The Politics } \\
\text { of Pesticides," Consumer Union Reports, Aug. 1969 } \\
\text { (pp. 3910-3911) }\end{array}$ & $\begin{array}{l}\text { 91st, 1st, and } \\
\text { 2nd }\end{array}$ \\
\hline 1971 & House & $\begin{array}{l}\text { Agriculture-Environmental and Consumer Protection } \\
\text { Appropriations for } 1972 \text {. Part } 2 \text {. } \\
\text { Hearings, Department of Agriculture } \\
\text { Subcommittee of the Committee on Appropriations } \\
\text { Mar. 10, 15, and } 16 \\
\text { Y4.Ap6/1:Ag8/972/pt. } 2 \\
\text { - Written statement and testimony of G. W. Irving, Jr., } \\
\text { USDA-Agricultural Research Service } \\
\text { (pp. 359-361, 366, 492) } \\
\text { - Testimony of Roy L. Lovvorn, USDA-Cooperative State } \\
\text { Research Service (pp. 584-585) }\end{array}$ & 92nd, 1st \\
\hline 1971 & Senate & $\begin{array}{l}\text { Federal Environmental Pesticide Control Act } \\
\text { Hearings on S. 232, S. 272, S. 660, and S. } 745 \\
\text { Subcommittee on Agricultural Research and General } \\
\quad \text { Legislation. Committee on Agriculture and Forestry. } \\
\text { Mar. 23, 24, 25, and } 26 \\
\text { Y4.Ag8/2:P43/pt. } 1\end{array}$ & 92nd, 1st \\
\hline
\end{tabular}


TABLE 1 (continued)

\begin{tabular}{|c|c|c|c|}
\hline Year* & Source & $\begin{array}{l}\text { Title } \\
\text { Activity } \\
\text { Subcommittee/Committee } \\
\text { Hearing Date(s) (Year Published, If Different) } \\
\text { SuDoc Number }\end{array}$ & Congress \\
\hline & & $\begin{array}{l}\text { - Excerpts from the statement of Hon. Gaylord } \\
\text { Nelson, U.S. Senator from the State of } \\
\text { Wisconsin (pp. 140-143, 146) }\end{array}$ & \\
\hline & & $\begin{array}{l}\text { - Statement of Everett J. Dietrick, Rincon-Vitova } \\
\text { Insectaries (pp. 150-160) }\end{array}$ & \\
\hline & & $\begin{array}{l}\text { - Excerpts from the statement of Ned D. Bayley, } \\
\text { USDA-Science and Education (pp. 192, 194, 196) }\end{array}$ & \\
\hline & & $\begin{array}{l}\text { - Exchange between Sen. James B. Allen and Fred H. } \\
\text { Tschirley, USDA-Environmental Quality Activities, } \\
\text { Pesticides (pp. 206-207) }\end{array}$ & \\
\hline & & $\begin{array}{l}\text { - Exchange between Sen. James B. Allen and } \\
\text { Francis J. Mulhern, USDA-Agricultural Research } \\
\text { Service (p. 210) }\end{array}$ & \\
\hline & & $\begin{array}{l}\text { - Excerpts from statement of Harry L. Graham, National } \\
\text { Farmers Organization (pp. 274-275, 277) }\end{array}$ & \\
\hline & & $\begin{array}{l}\text { - Excerpt from statement of Reuben L. Johnson, National } \\
\text { Farmers Union (pp. 282-283) }\end{array}$ & \\
\hline & & $\begin{array}{l}\text { Excerpt from statement of Clifford G. Mclntyre, } \\
\text { American Farm Bureau Federation (pp. 348-349) }\end{array}$ & \\
\hline & & $\begin{array}{l}\text { Exchange between Charles F. Wurster, State University } \\
\text { of New York-Stony Brook and Sen. Carl T. Curtis } \\
\text { (pp. 481-486) }\end{array}$ & \\
\hline & & $\begin{array}{l}\text { - Exchange between Robert van den Bosch, University of } \\
\text { California, Berkeley and Sen. James B. Allen (p. 631) }\end{array}$ & \\
\hline \multirow[t]{6}{*}{1971} & \multirow[t]{6}{*}{ Senate } & $\begin{array}{l}\text { Water Pollution Control Legislation. Agricultural Runoff. } \\
\text { Part 6. (Committee Serial No. 92-H11) } \\
\text { Hearings on S. } 75, \text { S. } 192, \text { S. 280, S. } 281, \text { S. } 523, \text { S. } 601 \text {, } \\
\quad \text { S. } 679, \text { S. } 927, \text { S. } 1011, \text { S. } 1012, \text { S. } 1013, \text { S. } 1014 \text {, } \\
\text { S. } 1015 \text {, and S. } 1017 \\
\text { Subcommittee on Air and Water Pollution. Committee } \\
\quad \text { on Public Works. } \\
\text { Apr. } 2 \\
\text { Y4.P96/10:92-H11/pt. } 6\end{array}$ & $92 \mathrm{nd}, 1 \mathrm{st}$ \\
\hline & & $\begin{array}{l}\text { - Exchange between Dr. George E. Smith, University of } \\
\text { Missouri and Sen. Thomas F. Eagleton (pp. 2532-2533) }\end{array}$ & \\
\hline & & $\begin{array}{l}\text { - Excerpt from statement of Gordon Shafer, National } \\
\text { Farmers Organization (pp. 2569-2570) }\end{array}$ & \\
\hline & & $\begin{array}{l}\text { - Excerpts from “Economic Implications of Pollution } \\
\text { Resulting from Agriculture," by J. C. Headley, } \\
\text { University of Missouri-Columbia (pp. 2663, 2664) }\end{array}$ & \\
\hline & & $\begin{array}{l}\text { - Excerpt from "Pesticide Pollution from Agricultural Sources," } \\
\text { by the Staff of the Dept. of Entomology, } \\
\text { University of Missouri-Columbia (pp. 2812-2813) }\end{array}$ & \\
\hline & & $\begin{array}{l}\text { - Excerpts from "Disposal of Solid Agricultural } \\
\text { Wastes-Concepts and Principles," by Raymond C. } \\
\text { Loehr, Cornell University (pp. 3185-3187) }\end{array}$ & \\
\hline
\end{tabular}




\begin{tabular}{|c|c|c|c|}
\hline Year* & Source & $\begin{array}{l}\text { Title } \\
\text { Activity } \\
\text { Subcommittee/Committee } \\
\text { Hearing Date(s) (Year Published, If Different) } \\
\text { SuDoc Number }\end{array}$ & Congress \\
\hline 1971 & Senate & $\begin{array}{l}\text { Chemicals and the Future of Man } \\
\text { Hearings } \\
\text { Subcommittee on Executive Reorganization and } \\
\text { Government Research. Committee on } \\
\text { Government Operations. } \\
\text { Apr. } 6 \text { and } 7 \\
\text { Y4.G74/6:C42 } \\
\text { - Exchange between Dr. Samuel S. Epstein, Harvard } \\
\text { Medical School and Sens. Abraham Ribicoff and } \\
\text { Jacob K. Javits (pp. 12-14) } \\
\text { - Exchange between Sen. Charles Percy and Sen. } \\
\text { Abraham Ribicoff (p. 101) }\end{array}$ & 92nd, 1st \\
\hline 1972 & Senate & $\begin{array}{l}\text { Federal Environmental Pesticide Control Act. Part II. } \\
\text { Hearings on H. R. } 10729 \\
\text { Subcommittee on Agricultural Research and General } \\
\quad \text { Legislation. Committee on Agriculture and Forestry. } \\
\text { Mar. } 7 \text { and } 8 \\
\text { Y4.Ag8/2:P43/pt. } 2 \\
\text { - Excerpt from statement of Sen. Gaylord Nelson } \\
\text { (pp. } 67,74-76 \text { ) } \\
\text { - Excerpts from statement of T. C. Byerly, USDA-Science } \\
\text { and Education (pp. 112, 113, 114) } \\
\text { - Excerpt from statement of Paul Brooks, Sierra Club (p. 124) } \\
\text { - Excerpt from statement of Thomas R. Garrett, Friends } \\
\text { of the Earth (pp. 227-228) } \\
\text { - Excerpts from statement of Reuben L. Johnson, National } \\
\text { Farmers Union (pp. 234, 235) }\end{array}$ & 92nd, 2nd \\
\hline 1973 & House & $\begin{array}{l}\text { Agriculture-Environmental and Consumer Protection } \\
\text { Appropriations for 1974. Part } 8 \text {. Miscellaneous. } \\
\text { Hearings } \\
\text { Subcommittee of the Committee on Appropriations } \\
\text { Mar. } 26 \\
\text { Y4.Ap6/1:Ag8/974/pt. } 8 \\
\text { - Excerpts from "Memorandum for the Chairman," Vol. III, } \\
\text { "Relationship of Pesticides to Environmental Issues" } \\
\text { (pp. 634-658, 750-759, 763-770, 786-790, } \\
\text { 815-841, 869-871) }\end{array}$ & 93rd, 1st \\
\hline 1974 & Senate & $\begin{array}{l}\text { Fertilizer Supply, Demand, and Prices. Part } 2 . \\
\text { Hearing } \\
\text { Subcommittee on Agricultural Credit and Rural } \\
\quad \text { Electrification. Committee on Agriculture and Forestry. } \\
\text { Mar. } 8 \\
\text { Y4.Ag8/2:F41/5/pt. } 2 \\
\text { - Excerpts from statement "Alternatives to Crop Production } \\
\text { with Fertilizer Supply Shortages," by R. A. Wiese, } \\
\text { Cooperative Extension Service, Lincoln, NE (pp. 337, 338) }\end{array}$ & 93rd, 2nd \\
\hline
\end{tabular}

Note: While bulleted items do not explicitly mention organic agriculture, these allude to some or all of its practices, criticize a nonchemical approach to agricultural production, or discuss concerns about and/or benefits of conventional agriculture's practices.

${ }^{*}$ Year during which the hearings were held. 
either. However, these Congressional hearings refer to practices recognized by many as "organic," including:

- biological control of insect pests and plant pathogens, ${ }^{19}$ especially by "habitat management ... [trying] in every way possible to diversify nature again with various techniques of strip farming and trap crops"; ${ }^{20}$

- cultural control methods, such as crop rotations that decrease pest and pathogen survival, maintain or increase soil fertility, and/or reduce soil erosion $;^{21}$ and

- "integrated control," which combines biological and cultural controls with pesticides, particularly selective rather than broad-spectrum ones, in order to reduce pest and pathogen populations to acceptable levels rather than to eradicate them. In fact, all the entries in Table 1 mention "integrated control" or "integrated pest management," with the exception of the last entry. This approach appears as part of the USDA definition of organic farming, which follows.

It is not until the 1975 Special Oversight Hearings on Agricultural Research and Development ${ }^{22}$ (Table 2) that USDA or government officials, or individuals and groups called to testify, use the term "organic." From this point forward, the term "organic" appears as an index term in the CIS Cumulative Indexes. ${ }^{23}$

The USDA's definition of "organic farming" appeared in the 1980 Report and Recommendations on Organic Farming (Table 2). The research study team reviewed and synthesized a range of definitions and practices named as "organic." Their definition stated as follows:

Organic farming is a production system which avoids or largely excludes the use of synthetically compounded fertilizers, pesticides, growth regulators, and livestock feed additives. To the maximum extent feasible, organic farming systems rely upon crop rotations, crop residues, animal manures, legumes, green manures, off-farm organic wastes, mechanical cultivation, mineral-bearing rocks, and aspects of biological pest control to maintain soil productivity and tilth, to supply plant nutrients, and to control insects, weeds, and other pests. ${ }^{24}$

Many USDA researchers, and those at U.S. land grant institutions, agreed with the USDA's 1980 definition, but as Warren Sahs, an 
TABLE 2. A Chronological Listing of Relevant Congressional Hearings, Legislation, and Selected USDA-Sponsored Documents, Published Between 1975 and 1989, Which Specifically Discuss or Pertain to Organic Agriculture, Research, and Consumerism

\begin{tabular}{|c|c|c|c|}
\hline Year* & Source & $\begin{array}{l}\text { Title } \\
\text { Activity } \\
\text { Subcommittee/Committee/Service } \\
\text { Hearing Date(s) (Year Published, If Different) } \\
\text { SuDoc Number }\end{array}$ & Congress \\
\hline 1975 & $\begin{array}{l}\text { House } \\
\text { Oversight } \\
\text { Hearings }\end{array}$ & $\begin{array}{l}\text { Agricultural Research and Development. Special } \\
\text { Part II (Committee Serial No. 51). } \\
\text { Hearings } \\
\text { Subcommittee on Science, Research and Technology } \\
\text { and Subcommittee on Domestic and International } \\
\text { Scientific Planning and Analysis. } \\
\text { Committee on Science and Technology. } \\
\text { Sept. 23, 24, 25, 30; Oct. 1, 2, 24, and } 25 \text { (1976) } \\
\text { Y4.Sci2:94-1/51 } \\
\text { - Exchange between T. W. Edminster, USDA-Agricultural } \\
\text { Research Service, and Rep. George E. Brown, Jr. (pp.110-112) } \\
\text { - Excerpt from statement of Dr. Barry Commoner, Center } \\
\text { for the Biology of Natural Systems, Washington University } \\
\text { (pp. 509-510) } \\
\text { - Exchange between Dr. Commoner and Rep. James W. } \\
\text { Symington (pp. 548-549) }\end{array}$ & 94th, 1st \\
\hline 1977 & Congress & $\begin{array}{l}\text { P. L. 95-113 Food and Agriculture Act of 1977, Title XIV } \\
\text { National Agricultural Research, Extension, and Teaching } \\
\text { Policy Act of } 1977 \\
\text { Subtitle F (Small Farm Research and Extension), Section } 1440 \\
\text { (Small Farm Research and Extension Programs) } \\
91 \text { Stat. } 1005-1006 \\
\text { Sept. } 29 \\
\text { - Emphasis on small-farms research is connected, in later } \\
\text { hearings, with research on organic agricultural methods }\end{array}$ & 95th \\
\hline 1977 & Congress & $\begin{array}{l}\text { P. L. } 95-113 \text { Food and Agriculture Act of 1977, Title XIV } \\
\text { National Agricultural Research, Extension, } \\
\quad \text { and Teaching Policy Act of } 1977 \\
\text { Subtitle J (Studies), Section } 1461 \text { (Organic Farming Study) } \\
91 \text { Stat. 1016-1017 } \\
\text { Sept. } 29\end{array}$ & 95th \\
\hline 1977 & House & $\begin{array}{l}\text { Obstacles to Strengthening Family Farm System } \\
\text { (Committee Serial No. 95-BB) } \\
\text { Hearings } \\
\text { Subcommittee on Family Farms, Rural Development, and } \\
\text { Special Studies. Committee on Agriculture. } \\
\text { Sept. 30; Oct. 15, 28, and } 29 \\
\text { Y4.Ag8/1:F21/3 } \\
\text { - Excerpt from statement of William H. Schmidt, Windham } \\
\text { (VT) Regional Planning and Development Commission (p. 35) } \\
\text { - Excerpt from statement of Susan Redlich, MA Dept. } \\
\text { of Agriculture (p. 81) } \\
\text { - Statement of Janet Libertoff, National Organic Farmers } \\
\text { Association (pp. 132-134) } \\
\text { - Statement of Francis Angier, National Organic Farmers } \\
\text { Association (pp. 138-141) }\end{array}$ & 95th, 1st \\
\hline
\end{tabular}




\section{TABLE 2 (continued)}

\begin{tabular}{|c|c|c|c|}
\hline Year* & Source & $\begin{array}{l}\text { Title } \\
\text { Activity } \\
\text { Subcommittee/Committee/Service } \\
\text { Hearing Date(s) (Year Published, If Different) } \\
\text { SuDoc Number }\end{array}$ & Congress \\
\hline & & $\begin{array}{l}\text { - Excerpt from statement of Kevin Hamilton, Farmer (p. 154) } \\
\text { - Statement of Howard Prussack, Farmer (pp. 164-167) } \\
\text { - Excerpt from statement of Fritz Griffin, Northern Community } \\
\text { Investment Corporation (p. 173) } \\
\text { - Excerpt from statement of Russel Schwandt, Minnesota } \\
\text { Agri-Growth Council (pp. 249-250) } \\
\text { - Excerpt from statement of Maxine McKeown, National } \\
\text { Catholic Rural Life Conference (p. 294) } \\
\text { - Exchange between Rep. Richard Nolan and Gloria and } \\
\text { Pedro Castex, New Life Farm (pp. 525-527) } \\
\text { - Excerpts from statement of Howard Beeman, Farmer } \\
\text { (pp. 531-532, 535-537) }\end{array}$ & \\
\hline 1977 & Senate & $\begin{array}{l}\text { Priorities in Agricultural Research of the U.S. Department } \\
\text { of Agriculture. Part } 1 . \\
\text { Hearings } \\
\text { Subcommittee on Administrative Practice and Procedure. } \\
\text { Committee on the Judiciary. } \\
\text { Oct. } 19 \text { and } 20 \text { [(1978]) } \\
\text { Y4.J89/2:Ag8/4/pt.1 } \\
\text { - Testimony of Ardell Anderson, Living Farms, Tracy, MN (pp. 3-7) } \\
\text { - Exchange between Ben H. Radcliffe, South Dakota } \\
\text { Farmers Union, and Sen. James Abourezk (p. 13) } \\
\text { - Excerpt from testimony of Dr. Patrick Madden, Pennsylvania } \\
\text { State University (p. 16) } \\
\text { - Excerpts from testimony of Allen Thompson, University } \\
\text { of New Hampshire (p. 30, 32) } \\
\text { - Exchange between Allen Thompson and Sen. James } \\
\text { Abourezk (pp. 35-36) } \\
\text { - Exchange between Martin Douglas Strange, Center } \\
\text { for Rural Affairs, and Sen. James Abourezk (p. 76) } \\
\text { - Testimony of James Nielson, USDA-Conservation, } \\
\text { Research and Education, et al. (pp. 117-129) } \\
\text { - Testimony of William Lockeretz, Center for the Biology } \\
\text { of Natural Systems, Washington University (pp.142-161) }\end{array}$ & 95th, 1st \\
\hline 1977 & Senate & $\begin{array}{l}\text { Priorities in Agricultural Research of the U. S. Department } \\
\text { of Agriculture-Appendix. Part } 2 . \\
\text { Appendix to Hearings } \\
\text { Subcommittee on Administrative Practice and Procedure. } \\
\text { Committee on the Judiciary. } \\
\text { Various dates, } 1977-1978 \text { (1978) } \\
\text { Y4.J89/2:Ag8/4/pt.2 } \\
\text { - Letter from Lee Fryer, Food and Earth Services, with two } \\
\text { enclosures, to Sen. James Abourezk (pp. 1-23) } \\
\text { - Statement by Organic Gardening and Farming Research Center, } \\
\text { Richard Harwood, Director, to the Subcommittee (pp. 24-33) }\end{array}$ & 95th, 1st \\
\hline
\end{tabular}




\begin{tabular}{|c|c|c|c|}
\hline Year* & Source & $\begin{array}{l}\text { Title } \\
\text { Activity } \\
\text { Subcommittee/Committee/Service } \\
\text { Hearing Date(s) (Year Published, If Different) } \\
\text { SuDoc Number }\end{array}$ & Congress \\
\hline & & $\begin{array}{l}\text { - Letter from M. D. Thorne, American Society of Agronomy, } \\
\text { to Sen. James Abourezk (pp. 43-44) }\end{array}$ & \\
\hline & & $\begin{array}{l}\text { - Document entitled "Conventional v. Organic Farming," by Samuel } \\
\text { R. Aldrich, University of Illinois, Urbana-Champaign (pp. 45-47) }\end{array}$ & \\
\hline & & $\begin{array}{l}\text { - Letter from Roy M. Kottman, The Ohio State University, to Sen. } \\
\text { Strom Thurmond (pp. 70-74) }\end{array}$ & \\
\hline & & $\begin{array}{l}\text { - Letter from J. H. Fowler, Colorado Organic Growers' and } \\
\text { Marketers' Association to Corey Rosen (p. 109) }\end{array}$ & \\
\hline & & $\begin{array}{l}\text { - Letter from Dennis Demmel, Midwest Organic Producers' } \\
\text { Association to Corey Rosen, with enclosures (pp. 114-124) }\end{array}$ & \\
\hline & & $\begin{array}{l}\text { - Letter from J. Francis Angier, organic farmer from VT, to } \\
\text { Sen. James Abourezk (pp. 124-126) }\end{array}$ & \\
\hline & & $\begin{array}{l}\text { - Letter from Bluefford G. Hancock, Texas A \& M University, } \\
\text { with enclosures, to Sen. James Abourezk (pp. 127-135) }\end{array}$ & \\
\hline & & $\begin{array}{l}\text { - Letter from Frank L. Bentz, Jr., University of Maryland, with } \\
\text { enclosure, to Sen. James Abourezk (pp. 136-139) }\end{array}$ & \\
\hline & & $\begin{array}{l}\text { - Letter from James F. Tammen, University of Minnesota, } \\
\text { with enclosure, to Sen. James Abourezk (pp. 140-161) }\end{array}$ & \\
\hline & & $\begin{array}{l}\text { - Letter from Hunter Follett, Kansas State University, to } \\
\text { Sen. James Abourezk (pp. 162-163) }\end{array}$ & \\
\hline & & $\begin{array}{l}\text { - Letter from R. Grant Seals, University of Nevada, with } \\
\text { enclosures, to Sen. James Abourezk (pp. 164-191) }\end{array}$ & \\
\hline & & $\begin{array}{l}\text { - Letter from Allen V. Barker, University of Massachusetts, } \\
\text { to Sen. James Abourezk (p. 192) }\end{array}$ & \\
\hline & & $\begin{array}{l}\text { - Letter from Henry W. Garren, University of Georgia, } \\
\text { to Sen. James Abourezk (p. 193) }\end{array}$ & \\
\hline & & $\begin{array}{l}\text { - Letter from C. E. Howes, Virginia Polytechnic Institute } \\
\text { and State University, to Sen. James Abourezk (pp. 194-195) }\end{array}$ & \\
\hline & & $\begin{array}{l}\text { - Letter from James H. Anderson, Michigan State University, } \\
\text { with enclosure, to Sen. James Abourezk (pp. 200-202) }\end{array}$ & \\
\hline & & $\begin{array}{l}\text { - Letter from Roy M. Kottman, The Ohio State University, } \\
\text { to Sen. James Abourezk (pp. 203-204) }\end{array}$ & \\
\hline & & $\begin{array}{l}\text { - Letter from H. A. Keener, University of New Hampshire, } \\
\text { to Sen. James Abourezk (p. 224) }\end{array}$ & \\
\hline & & $\begin{array}{l}\text { - Letter from W. Wayne Hinish, The Pennsylvania State } \\
\text { University, to Sen. James Abourezk (p. 225) }\end{array}$ & \\
\hline & & $\begin{array}{l}\text { - Letter from Gerald A. Donovan, University of Rhode Island, } \\
\text { to Sen. James Abourezk (pp. 266-267) }\end{array}$ & \\
\hline & & $\begin{array}{l}\text { - Letter from Kenneth E. Wing, University of Maine, } \\
\text { to Sen. James Abourezk (pp. 297-298) }\end{array}$ & \\
\hline & & $\begin{array}{l}\text { - Letter from Merle H. Jensen, University of Arizona, } \\
\text { to Sen. James Abourezk (p. 299) }\end{array}$ & \\
\hline & & $\begin{array}{l}\text { - Letter from Grant Vest, Oklahoma State University, } \\
\text { to Sen. James Abourezk (pp. 302-303) }\end{array}$ & \\
\hline & & $\begin{array}{l}\text { - Letter from Winfred Thomas, Alabama A \& M University, } \\
\text { to Sen. James Abourezk (pp. 306-307) }\end{array}$ & \\
\hline & & $\begin{array}{l}\text { - Letter from K. R. Tefertiller, University of Florida, } \\
\text { to Sen. James Abourezk (pp. 332-333) }\end{array}$ & \\
\hline
\end{tabular}


TABLE 2 (continued)

\begin{tabular}{|c|c|c|c|}
\hline Year* & Source & $\begin{array}{l}\text { Title } \\
\text { Activity } \\
\text { Subcommittee/Committee/Service } \\
\text { Hearing Date(s) (Year Published, If Different] ) } \\
\text { SuDoc Number }\end{array}$ & Congress \\
\hline
\end{tabular}

- Letter from E. C. Stevenson, Oregon State University, to Sen. James Abourezk (pp. 344-345)

- Letter from Elmer R. Kiehl, University of Missouri-Columbia, to Sen. James Abourezk (p. 346)

- Letter from Walter E. Splittstoesser, University of Illinois at Urbana-Champaign, with enclosure, to Sen. James Abourezk (pp. 347-348)

- Letter from George A. Bowman, Washington State University, to Sen. James Abourezk (p. 349)

- Letter from K. A. Gilles, North Dakota State University, to Sen. James Abourezk (pp. 366-367)

- Letter from Donald F. Crossan, University of Delaware, to Sen. James Abourezk (p. 369)

- Letter from Louis N. Wise, Mississippi State University, to Sen. James Abourezk (p. 376)

- Letter from R. Dennis Rouse, Auburn University, to Sen. James Abourezk (pp. 377-378)

- Letter from John L. Skinner, University of Wisconsin, to Sen. James Abourezk (p. 408)

- Letter from Samuel C. Wiggans, University of Vermont, with enclosure, to Sen. James Abourezk (pp. 457-461)

- Letter from Lloyd F. Seatz, University of Tennessee, to Sen. James Abourezk (pp. 496-497)

- Letter from W. K. Kennedy, Cornell University, to Sen. James Abourezk (p. 498)

- Letter from Louis M. Thompson, lowa State University, to Sen. James Abourezk (p. 545)

- Letter from Luther P. Anderson, Clemson University, to Sen. James Abourezk (p. 546)

- Letter from Delwyn Dearborn, South Dakota State University, with enclosure, to Sen. James Abourezk (pp. 547-552)

- Doctoral dissertation (excerpts), entitled "The Economics of Organic Farming," by Robert C. Oelhaf (pp. 806-953)

- Countryside magazine article about organic farmer Eliot Coleman, by Jerry and Gretchen Belanger (pp. 1010-1016)

- Report entitled "European Biological Agriculture" by Eliot Coleman (pp. 1020-1038)

- Document entitled "The Movement for an Ecological Agriculture and Appropriate Technology" by Isao Fujimoto (pp. 1039-1054)

- Article entitled "The New Alchemists" by Wade Greene (pp. 1055-1060)

- Article entitled "Can We Take the Chemicals Out of the Corn Belt?" by William Lockeretz (pp. 1060-1064)

- Chapter 16, "Toward a Self-sustaining Agriculture," from the book Radical Agriculture by Richard Merrill (pp. 1100-1143) 


\begin{tabular}{|c|c|c|c|}
\hline Year* & Source & $\begin{array}{l}\text { Title } \\
\text { Activity } \\
\text { Subcommittee/Committee/Service } \\
\text { Hearing Date(s) (Year Published, If Different] ) } \\
\text { SuDoc Number }\end{array}$ & Congress \\
\hline & & $\begin{array}{l}\text { - Excerpts from summary of "The People and the University" } \\
\text { (pp. 1169-1173, 1176-1185, 1188-1191, 1196-1201,1206-1209) }\end{array}$ & \\
\hline & & $\begin{array}{l}\text { - Article entitled "An Alternative Agriculture Policy: Strategies } \\
\text { for Change" by Garth Youngberg (pp. 1210-1214) }\end{array}$ & \\
\hline & & $\begin{array}{l}\text { - Article entitled "Organic Farming Can Feed the World" } \\
\text { by Steve Sherman (pp. 1214-1217) }\end{array}$ & \\
\hline & & $\begin{array}{l}\text { - Article entitled "Organic Farming Cannot Feed the World" } \\
\text { by Hiram Perry (pp. 1217-1220) }\end{array}$ & \\
\hline & & $\begin{array}{l}\text { - Article entitled "Motivations and Practices of Organic Farmers" } \\
\text { by Sarah Wernick and William Lockeretz (pp. 1221-1225) }\end{array}$ & \\
\hline & & $\begin{array}{l}\text { - Article entitled "The Day of the Locust" by Daniel Zwerdling } \\
\text { (pp. 1320-1324) }\end{array}$ & \\
\hline & & $\begin{array}{l}\text { - Memorandum concerning an organic farming survey of FHA } \\
\text { county supervisors from Corey Rosen to Sen. James } \\
\text { Abourezk (pp. 1426-1427) }\end{array}$ & \\
\hline 1978 & USDA & $\begin{array}{l}\text { Improving Soils with Organic Wastes } \\
\text { Report to Congress required in } 91 \text { Stat. 1016-1017 } \\
\text { No additional date available } \\
\text { A1.2:So3/5 }\end{array}$ & \\
\hline \multirow[t]{3}{*}{1980} & Senate & $\begin{array}{l}\text { Nutrition Labeling and Information. Part IV. Hearing on S. } 1651 \\
\text { Subcommittee on Nutrition. Committee on Agriculture, } \\
\quad \text { Nutrition, and Forestry. } \\
\text { Apr. } 1 \\
\text { Y4.Ag8/3:N95/2/pt.4 }\end{array}$ & 96th, 2nd \\
\hline & & - Statement of Paul Keene, Walnut Acres (pp. 22-24, 95-106) & \\
\hline & & • "The Walnut Acres Story" (pp. 107-118) & \\
\hline 1980 & USDA & $\begin{array}{l}\text { Report and Recommendations on Organic Farming } \\
\text { Report } \\
\text { USDA-Study Team on Organic Farming } \\
\text { July } \\
\text { A1.2:Or3/3 }\end{array}$ & \\
\hline 1981 & USDA & $\begin{array}{l}\text { A Bibliography for Small and Organic Farmers 1920-78 } \\
\text { Bibliography } \\
\text { Science and Education Administration/J. W. Schwartz } \\
\text { April }\end{array}$ & \\
\hline 1981 & Congress & $\begin{array}{l}\text { P. L. 97-98 Agriculture and Food Act of 1981, Title XIV } \\
\text { National Agricultural Research, Extension, and Teaching } \\
\text { Policy Act Amendments of 1981 } \\
\text { Section } 1402 \text { (Findings), subpart (10) (D) (v) } \\
95 \text { Stat. } 1295 \text { Dec. } 22\end{array}$ & 97th \\
\hline \multirow[t]{3}{*}{1982} & House & $\begin{array}{l}\text { Sustainable Agricultural Systems (Committee Serial No. 97-PPP) } \\
\text { Hearings } \\
\text { Subcommittee on Department Operations, Research, } \\
\quad \text { and Foreign Agriculture. Committee on Agriculture. } \\
\text { Apr. 16, 22, and } 27 \\
\text { Y4.Ag8/1:97-PPP }\end{array}$ & 97th, 2nd \\
\hline & & $\begin{array}{l}\text { - Statement of Anson R. Bertrand, USDA-Science and Education } \\
\text { Administration, accompanied by Garth Youngberg, } \\
\text { Organic Farming Coordinator (pp. 115-118) }\end{array}$ & \\
\hline & & $\begin{array}{l}\text { - Exchanges between Rep. George E. Brown Jr., Anson } \\
\text { Bertrand and Garth Youngberg (pp. 118-122) }\end{array}$ & \\
\hline
\end{tabular}


TABLE 2 (continued)

\begin{tabular}{|c|c|c|c|}
\hline Year* & Source & $\begin{array}{l}\text { Title } \\
\text { Activity } \\
\text { Subcommittee/Committee/Service } \\
\text { Hearing Date(s) (Year Published, If Different) } \\
\text { SuDoc Number }\end{array}$ & Congress \\
\hline & & $\begin{array}{l}\text { - Letter from Rep. George E. Brown Jr. to John R. Block, } \\
\text { Secretary of Agriculture (pp. 276-281) }\end{array}$ & \\
\hline & & $\begin{array}{l}\text { Letter from Michael J. Masterson, Congressional Affairs, } \\
\text { USDA, on behalf of John R. Block, to Rep. George E. Brown Jr. } \\
\text { (pp. 288-293) }\end{array}$ & \\
\hline 1982 & Senate & $\begin{array}{l}\text { Innovative Farming Act of } 1982 \\
\text { S. } 2485 \\
\text { May } 5 \\
\text { Accessed at http://thomas.loc.gov/home/search.html }\end{array}$ & 97th, 2nd \\
\hline 1982 & House & $\begin{array}{l}\text { Organic Farming Act of } 1982 \text { (Committee Serial No. 97-SSS) } \\
\text { Hearing on H. R. } 5618 \text { (introduced Feb. 24, 1982) } \\
\text { Subcommittee on Forests, Family Farms, and Energy. } \\
\quad \text { Committee on Agriculture. } \\
\text { June } 10 \\
\text { Y4.Ag8/1:97-SSS }\end{array}$ & 97th, 2nd \\
\hline 1982 & House & $\begin{array}{l}\text { Organic Farming Act of } 1982 \\
\text { H. Rpt. } 97-733 \\
\text { Aug. } 12(1984) \\
\text { Y1.1/2: Serial } 13487\end{array}$ & 97th, 2nd \\
\hline \multirow[t]{7}{*}{1983} & House & $\begin{array}{l}\text { Miscellaneous Conservation (Committee Serial No. 98-13) } \\
\text { Hearings on Soil and Water Conservation Concerns } \\
\text { and Issues, and on H. R. 568, 2714, 2928, 3457, 3903, } \\
\text { and } 3906 \\
\text { Subcommittee on Conservation, Credit, and Rural Development. } \\
\text { Committee on Agriculture. } \\
\text { May } 4 \text { and Sept. } 20 \text { (1984) } \\
\text { Y4.Ag8/1:98-13 }\end{array}$ & 98th, 1st \\
\hline & & $\begin{array}{l}\text { - Report of The Wildlife Society Committee on Habitat on } \\
\text { Private Lands, by M. Rupert Cutler and Richard L. Plunkett } \\
\text { (pp. 254-257) }\end{array}$ & \\
\hline & & $\begin{array}{l}\text { Exchange between Rep. Jim Weaver and Clare I. Harris, } \\
\text { Acting Administrator, USDA-Cooperative State Research } \\
\text { Service (p. 355) }\end{array}$ & \\
\hline & & - Statement of Rep. Jim Weaver (pp. 385-387) & \\
\hline & & $\begin{array}{l}\text { - Statement of Clare I. Harris, Acting Administrator, } \\
\text { USDA-Cooperative State Research Service (pp. 389-391) }\end{array}$ & \\
\hline & & $\begin{array}{l}\text { - Testimony of Norman Berg, Conservation Society of America } \\
\text { (pp. 391-395) }\end{array}$ & \\
\hline & & $\begin{array}{l}\text { - Letter from Mrs. Lou Holden, with enclosures, to Mario } \\
\text { Castillo (pp. 434-439) }\end{array}$ & \\
\hline \multirow[t]{2}{*}{1983} & House & $\begin{array}{l}\text { Agricultural Productivity Act of } 1983 \text { (Committee Serial No. 98-50) } \\
\text { Hearing on H. R. } 2714\end{array}$ & 98th, 1st \\
\hline & & $\begin{array}{l}\text { Subcommittee on Department Operations, Research, and } \\
\text { Foreign Agriculture. Committee on Agriculture. } \\
\text { Aug. } 3(1984) \\
\text { Y4.Ag8/1:98-50 }\end{array}$ & \\
\hline 1983 & House & $\begin{array}{l}\text { Improving the Productivity of American Farms } \\
\text { H. Rpt. 98-587 } \\
\text { Dec. } 9(1984) \\
\text { Y1.1/2: Serial } 13546\end{array}$ & 98th, 1st \\
\hline
\end{tabular}




\begin{tabular}{|c|c|c|c|}
\hline Year* & Source & $\begin{array}{l}\text { Title } \\
\text { Activity } \\
\text { Subcommittee/Committee/Service } \\
\text { Hearing Date(s) (Year Published, If Different] ) } \\
\text { SuDoc Number }\end{array}$ & Congress \\
\hline 1984 & Senate & $\begin{array}{l}\text { Agricultural Productivity Act of } 1983 \text { (S. Hrg. 98-1018) } \\
\text { Hearing on S. } 1128 \\
\text { Subcommittee on Agricultural Research and General Legislation. } \\
\quad \text { Committee on Agriculture, Nutrition, and Forestry. } \\
\text { June } 14 \\
\text { Y4.Ag8/3:S.Hrg. 98-1018 }\end{array}$ & 98th, 2nd \\
\hline \multirow[t]{19}{*}{1985} & \multirow[t]{19}{*}{ House } & $\begin{array}{l}\text { General Farm Bill of } 1985 \text { (Research, Extension, Teaching, } \\
\quad \text { and Export Programs) (Committee Serial No. 99-5, Part 4) } \\
\text { Hearings } \\
\text { Subcommittee on Department Operations, Research, } \\
\quad \text { and Foreign Agriculture. Committee on Agriculture. } \\
\text { Mar. } 27 \text { and Apr. } 4 \\
\text { Y4.Ag8/1:99-5/pt.4 }\end{array}$ & \multirow[t]{19}{*}{ 99th, 1st } \\
\hline & & $\begin{array}{l}\text { - Exchange between Orville G. Bentley, USDA-Science } \\
\text { and Education and Rep. Berkley Bedell (p. 27) }\end{array}$ & \\
\hline & & - Statement of William K. Kruesi, Cornell University (pp. 76-77) & \\
\hline & & - Statement of Rep. James Weaver (pp. 80-81) & \\
\hline & & $\begin{array}{l}\text { - Statement of Larry D. King, North Carolina State University } \\
\text { (pp. 81-84) }\end{array}$ & \\
\hline & & $\begin{array}{l}\text { - Excerpt from statement of Maureen K. Hinkle, National } \\
\text { Audubon Society (p. 88) }\end{array}$ & \\
\hline & & - Excerpt from written testimony of Orville G. Bentley (p. 104) & \\
\hline & & $\begin{array}{l}\text { - Excerpts from written statement of Peggy Wheeler Kainz, } \\
\text { National Center for Appropriate Technology (pp. 165, 168-169, } \\
171-172,174)\end{array}$ & \\
\hline & & $\begin{array}{l}\text { - Excerpts from written testimony of William K. Kruesi, Cornell } \\
\text { University (pp. 186-187, 189-192) }\end{array}$ & \\
\hline & & $\begin{array}{l}\text { - Written statement of Larry D. King, North Carolina State } \\
\text { University (pp. 193-198) }\end{array}$ & \\
\hline & & $\begin{array}{l}\text { - Excerpt from written statement of Maureen K. Hinkle, National } \\
\text { Audubon Society (pp. 215-217) }\end{array}$ & \\
\hline & & $\begin{array}{l}\text { - Excerpt from written testimony of James E. Bath, Michigan } \\
\text { State University (pp. 286-287) }\end{array}$ & \\
\hline & & $\begin{array}{l}\text { - Written testimony of Thomas C. Edens, Michigan State University } \\
\text { (pp. 290-298) }\end{array}$ & \\
\hline & & $\begin{array}{l}\text { - Written testimony of Tom Ellis, Michigan State University } \\
\text { (pp. 299-304) }\end{array}$ & \\
\hline & & $\begin{array}{l}\text { - Excerpts from written testimony of Catherine Lerza, Rural } \\
\text { Coalition (pp. } 337,346-349)\end{array}$ & \\
\hline & & $\begin{array}{l}\text { - Letter from J. Patrick Madden, The Pennsylvania State } \\
\text { University, to Rep. Jim Weaver (pp. 356-357) }\end{array}$ & \\
\hline & & $\begin{array}{l}\text { - Letter from Warren W. Sahs, University of Nebraska-Lincoln, } \\
\text { to Rep. Jim Weaver (p. 378) }\end{array}$ & \\
\hline & & $\begin{array}{l}\text { Written testimony of Robert Rodale, Regenerative } \\
\text { Agriculture Association and Rodale Press, Inc. } \\
\text { (pp. 380-383) }\end{array}$ & \\
\hline & & $\begin{array}{l}\text { - Written testimony of I. Garth Youngberg, Institute for } \\
\text { Alternative Agriculture, Inc. (pp. 393-400) }\end{array}$ & \\
\hline
\end{tabular}


TABLE 2 (continued)

\begin{tabular}{|c|c|c|c|}
\hline Year* & Source & $\begin{array}{l}\text { Title } \\
\text { Activity } \\
\text { Subcommittee/Committee/Service } \\
\text { Hearing Date(s) (Year Published, If Different] ) } \\
\text { SuDoc Number }\end{array}$ & Congress \\
\hline & House & $\begin{array}{l}\text { Directing the Secretary of Agriculture to Take Certain Actions } \\
\text { to Improve the Productivity of American Farmers, } \\
\text { and for Other Purposes } \\
\text { H. Rpt. } 99-126 \\
\text { May } 15 \text { (1987) } \\
\text { Y1.1/2: Serial } 13647\end{array}$ & 99th, 1st \\
\hline \multirow[t]{2}{*}{1985} & USDA & $\begin{array}{l}\text { Organic-Related Farming Systems Research FY82: A Directory } \\
\quad \text { of USDA and State Projects in CRIS (microform) } \\
\text { Report } \\
\text { Current Research Information System } \\
\text { September }\end{array}$ & \\
\hline & & $\begin{array}{l}\text { - Literature search mentioned by dissenting members of } \\
\text { Congress, in Organic Farming Act of 1982, H. Rpt. 97-733 }\end{array}$ & \\
\hline 1985 & Congress & $\begin{array}{l}\text { P. L. } 99-198 \text { Food Security Act of 1985, Title XIV (Agricultural } \\
\text { Research, Extension, and Teaching) } \\
\text { Subtitle A (General Provisions), Section } 1402 \text { (Findings) } \\
99 \text { Stat. } 1543 \\
\text { Dec. } 23\end{array}$ & 99th \\
\hline \multirow[t]{2}{*}{1985} & Congress & $\begin{array}{l}\text { P. L. 99-198 Food Security Act of 1985, Title XIV (Agricultural } \\
\text { Research, Extension, and Teaching) } \\
\text { Subtitle C (Agricultural Productivity Research), Section } 1464 \\
\quad \text { (Information Study) } \\
99 \text { Stat. } 1564 \\
\text { Dec. } 23\end{array}$ & 99th \\
\hline & & $\begin{array}{l}\text { - Requirement for the Secretary of Agriculture to collect } \\
\text { information about specific "organic" farming practices }\end{array}$ & \\
\hline
\end{tabular}

Note: If the entire document does not explicitly relate to organic agriculture, the specific pages that do so are cited. ${ }^{*}$ Year during which the hearing(s) were held.

authority in the area of organic farming, commented in 1982, "[W] do not call it organic." ${ }^{25} \mathrm{He}$ made the point, "We get tied up in semantics. We went through that in the middle 1970s in Nebraska, and we have gotten away from that, the polarity of these two different groups [organic vs. conventional farmers]. My written testimony indicates that we are thinking of alternate cropping systems-organic farming." 26

While Sahs painted a picture of improved communication about organic practices, the problem of semantics continued in the congressional and agricultural research arenas. Politicians created their own definitions of organic farming. At one extreme, the grower could add organic material (regardless of source) to the soil, as presented in the USDA's 1978 report Improving Soils with Organic Wastes (Table 2). This report suggested the use of human sewage sludge for soil amendment, part of 
the category of "off-farm organic wastes" later mentioned in the USDA's 1980 definition of organic farming, but deemed unacceptable under current NOP certification guidelines and by most organic producers. Representatives of the Rodale Institute, one of the early leaders in the U.S. organic movement, presented an ideal definition articulated by Ray Wolf:

Organic farming is using the very latest in technology, applied to current research, to fulfill the principles of good soil husbandry our forefathers adhered to . . . Organic farmers not only wish to avoid the use of chemical fertilizers and pesticides that can cause damage to soil and wildlife, and create toxic side effects in a variety of ways but they also are very much concerned about the prevention of erosion, the adding of humus and other organic matter to soil to improve fertility, the preservation of small family farms, localized marketing of food, energy conservation, and proper nutrition. $^{27}$

For the purposes of this discussion, Wolf's definition is a benchmark because it articulates the ideas and ideals of most organic growers of the era. Located throughout the various hearings, listed in Table 2, are examples of testimonies by organic growers about their farming methods and philosophies. ${ }^{28}$

There are two critical differences between the USDA's definition of organic farming and that of the majority of organic proponents. First, the USDA definition fails to recognize organic farming as a philosophy, which it is for many growers and consumers. ${ }^{29}$ The quasi-religious stance taken by some organic farmers likely slowed recognition of the need for research into the validity of organic methods. The 1983 testimony of Richard L. Thompson, a conventional farmer from Boone, Iowa who converted to organic methods, is an example: ${ }^{30}$

Organic, to me, is an inner feeling that affects the way you think and then changes the way you act toward the environment and your fellow man. Perhaps regeneration better explains our feelings....

There were problems [during the 10 years Thompson used conventional methods]. It seemed like the cattle were sick all the time and the pigs were sick so I was kind of in a corner in the natural. ... [W]e started learning about the part of God, that the Holy Spirit 
was going to be the teacher, and so a word came to us in a supernatural way that God was going to teach us how to farm, and here I had two degrees in agriculture and had lived on the farm all my life and I wondered how this could be.

So we made a dramatic switch.

In the follow-up to Thompson's testimony, Rep. George E. Brown, Jr. (D-Calif.) noted

In connection with the organic farming operation of the old Amish, that that seems to be based upon their spiritual convictions also. This is the proper way to treat the Earth, and that it complies with their interpretation of what the Lord provided in the Bible ...

However, I know that this administration has a number of bornagain Christians in it who don't feel the same way you do. ${ }^{31}$

Even the supportive Brown ended his discussion with Thompson with the comment: "I think that is another evidence of the wisdom of the Founding Fathers who felt we should keep religion out of politics"32_ and out of agricultural research efforts. The USDA's administrators and scientists, especially during the lean agricultural budget years of the early 1980s, were not interested in a philosophically driven research program.

The second difference stems from the precision of the USDA's definition. This precision fails to place organic farming, as a production system, into the larger and interconnected picture of American agriculture and society during the 1970s and 1980s. The larger context recognizes the loss of smaller family-owned farms, that is, those more likely to adopt organic practices successfully, rather than the increased acreages owned and/or farmed conventionally by corporations. A larger context also recognizes the rising costs of fuel and petrochemical-based fertilizers and many Americans' concerns about the environment and the effects of pesticide exposures, water and soil pollution, soil erosion, as well as a growing awareness of food production/processing methods and sources-of-origin. Clearly, this absence of a consistent, mutually acceptable definition of organic farming negatively affected any discussions that occurred because no one was speaking the same language, and this probably hampered the opportunities for research into organic methods during this time period. 


\section{DISCOVERING DOCUMENTATION}

The lack of a consistent definition and the resultant loose terminology additionally slowed the identification and retrieval of theses and other research reports mentioned during congressional hearings or in accompanying written testimony (Table 3). Online catalog searches of the National Agricultural Library's (NAL) collection revealed that "organic agriculture" or "organic farming," that is, terms that an interested reader or researcher might use, were not the preferred controlled vocabulary and neither phrase was particularly useful in keyword searches. The current NAL Thesaurus ${ }^{33}$ specifies "organic production" as the preferred vocabulary and indicates the phrase is synonymous with, and should be used for, the phrases "biodynamic farming," "organic agriculture," "organic culture," and "organic farming." Related terms include "alternative farming" and "sustainable agriculture." The difficulty in identifying documentation reflects the disconnect between terms employed popularly and used in the congressional hearings listed in Table 2 and the controlled vocabulary applied during the 1970-1989 time frame.

USDA officials mentioned ongoing graduate research in organic agriculture, or research report preparation, during hearings or in written communications with the Congress. Attempts to identify documentation of the graduate-level research through subject and keyword searches of the online catalogs of seven university libraries identified during a Congressional hearing were mostly unsuccessful. ${ }^{34}$ The institutions mentioned are Iowa State University, Kansas State University, Michigan State University, The Pennsylvania State University, University of Maine, University of Nebraska, and Washington State University. All of these institutions use Library of Congress (LC) subject headings. The Library of Congress currently uses "organic farming" as the preferred subject heading, enveloping the phrases "biodynamic agriculture," "biodynamic farming," "biological agriculture," "ecological agriculture," "organiculture," and "regenerative agriculture."35 "Sustainable agriculture" is a separate subject heading, with "alternative agriculture" serving as a "see-also" phrase. ${ }^{36}$

In the identification of the USDA-supported graduate research, success depended upon the use of the subject heading "organic farming" during the cataloging of the theses and dissertations. For example, Steven L. Kraten's 1979 MA thesis titled A Preliminary Examination of the Economic Performance and Energy Intensiveness of Organic and Conventional Small Grain Farms in the Northwest (Table 3) had "organic farming" as its third and final LC subject heading, and its identification 
TABLE 3. A Chronological Listing of USDA-Sponsored Graduate Research, and Other Reports Pertaining to Organic Agriculture Mentioned During the Hearings Found in Table 2

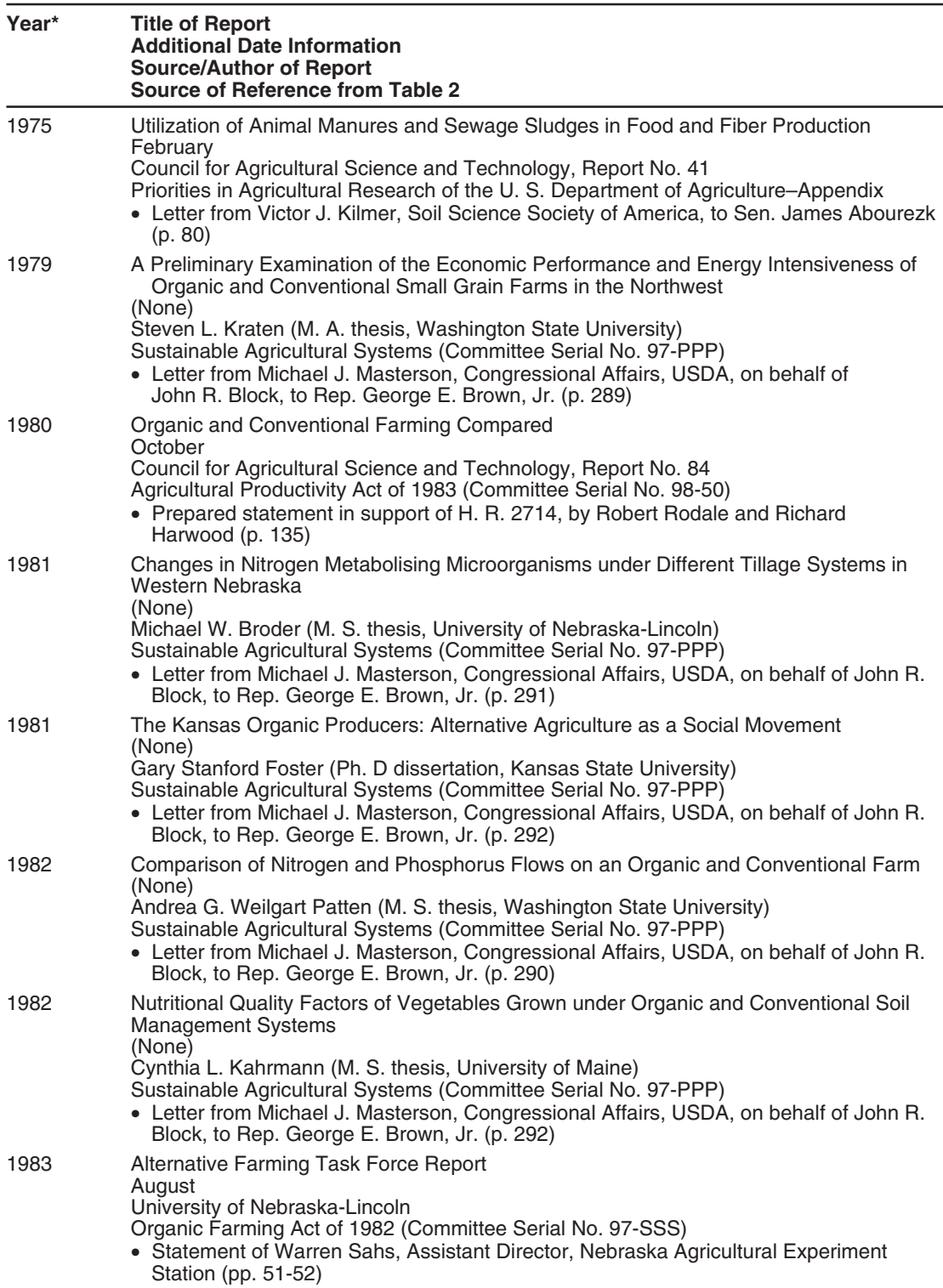

- Letter from Michael J. Masterson, Congressional Affairs, USDA, on behalf of John R. Block, to Rep. George E. Brown, Jr. (p. 292)

1982 Comparison of Nitrogen and Phosphorus Flows on an Organic and Conventional Farm (None)

Andrea G. Weilgart Patten (M. S. thesis, Washington State University)

Sustainable Agricultural Systems (Committee Serial No. 97-PPP)

- Letter from Michael J. Masterson, Congressional Affairs, USDA, on behalf of John R. Block, to Rep. George E. Brown, Jr. (p. 290)

$1982 \quad$ Nutritional Quality Factors of Vegetables Grown under Organic and Conventional Soil Management Systems

(None)

Cynthia L. Kahrmann (M. S. thesis, University of Maine)

Sustainable Agricultural Systems (Committee Serial No. 97-PPP)

- Letter from Michael J. Masterson, Congressional Affairs, USDA, on behalf of John R.

Block, to Rep. George E. Brown, Jr. (p. 292)

$1983 \quad$ Alternative Farming Task Force Report

August

University of Nebraska-Lincoln

Organic Farming Act of 1982 (Committee Serial No. 97-SSS)

- Statement of Warren Sahs, Assistant Director, Nebraska Agricultural Experiment

Station (pp. 51-52) 


\begin{tabular}{|c|c|}
\hline Year* & $\begin{array}{l}\text { Title of Report } \\
\text { Additional Date Information } \\
\text { Source/Author of Report } \\
\text { Source of Reference from Table } 2\end{array}$ \\
\hline 1983 & $\begin{array}{l}\text { Soil Microbial Biomass and Selected Soil Enzyme Activities on an Alternatively and a Con- } \\
\text { ventionally Managed Farm } \\
\text { (None) } \\
\text { Harvey Bolton (M. S. thesis, Washington State University) } \\
\text { Sustainable Agricultural Systems (Committee Serial No. 97-PPP) } \\
\text { - Letter from Michael J. Masterson, Congressional Affairs, USDA, on behalf of John R. } \\
\text { Block, to Rep. George E. Brown, Jr. (p. 290) }\end{array}$ \\
\hline 1984 & $\begin{array}{l}\text { Organic Farming: Current Technology and Its Role in a Sustainable Agriculture } \\
\text { American Society of Agronomy, Crop Science Society of America, and } \\
\text { Soil Science Society of America } \\
\text { ASA Special Publication No. } 46 \\
\text { Sustainable Agricultural Systems (Committee Serial No. 97-PPP) } \\
\text { - Statement of Anson R. Bertand, Science and Education, USDA, concerning the } 1981 \\
\text { symposium held by these societies about organic farming (p. 121) }\end{array}$ \\
\hline 1986 & $\begin{array}{l}\text { Conventional and Organic-Related Farming Systems Research: An Assessment of } \\
\text { USDA and State Research Projects } \\
\text { (None) } \\
\text { F. W. Schaller, H. E. Thompson, and C. M. Smith } \\
\text { Organic-Related Farming Systems Research FY } 82 \text { : A Directory of USDA and State } \\
\text { Projects in CRIS (microform) } \\
\text { Agricultural Productivity Act of 1983, Hearing on S. 1128, S. Hrg. 98-1018 } \\
\text { - Letter from Orville G. Bentley, Science and Education, USDA, to Rep. Joe Skeen } \\
\text { (pp. 15-16) }\end{array}$ \\
\hline 1986 & $\begin{array}{l}\text { Alternative Crops, Rotations, and Management Systems for the Palouse (Compost, Wheat, } \\
\text { Washington) } \\
\text { [(None]) } \\
\text { Walter Allen Goldstein (Ph.D. dissertation, Washington State University) } \\
\text { Sustainable Agricultural Systems (Committee Serial No. 97-PPP) } \\
\text { - Letter from Michael J. Masterson, Congressional Affairs, USDA, on behalf of John R. } \\
\text { Block, to Rep. George E. Brown, Jr. (p. 290) }\end{array}$ \\
\hline 1986 & $\begin{array}{l}\text { A Dynamic Simulation Model of the Transition from Conventional to Organic Farming } \\
\text { (None) } \\
\text { Stephan Dabbert (M. S. thesis, Pennsylvania State University) } \\
\text { Sustainable Agricultural Systems (Committee Serial No. 97-PPP) } \\
\text { - Letter from Michael J. Masterson, Congressional Affairs, USDA, on behalf of John R. } \\
\text { Block, to Rep. George E. Brown, Jr. (p. 292) }\end{array}$ \\
\hline
\end{tabular}

*Year of thesis acceptance or report publication.

in the catalog of Washington State University was straightforward. Similarly, Gary Stanford Foster's PhD dissertation, The Kansas Organic Producers: Alternative Agriculture as a Social Movement (Table 3), had "organic farming-Kansas" as the second of three subject headings. An NAL Quick Bibliography ${ }^{37}$ identified another Kansas State thesis-Lack of Integrated Studies of Farming Systems Hampers Transfer of Research to Organic Farms by James Richard Lukens-that had "organic farming-information services" as its first LC subject heading. However, this thesis does not fit the descriptions of USDA-supported research described by Michael J. Masterson in his 1982 letter to Rep. George E. Brown, Jr. 
It was difficult to identify directly the majority of the research conducted at the seven institutions and cited by Masterson. ${ }^{38}$ It was easy to miss this part of the early research record of USDA-supported organic research, unless the searcher combined the descriptions provided in Masterson's letter with subject knowledge; the term "organic" does not appear in the catalog descriptions of these early materials. As an example, Michael W. Broder's MS thesis, Changes in Nitrogen Metabolising Microorganisms under Different Tillage Systems in Western Nebraska (Table 3), had the following LC subject headings: "tillage-Nebraska"; "nitrification"; "bacteria, nitrifying"; and "soils-Nebraska-analysis." Other thesis author-subject heading combinations include the following (see Table 3):

- Andrea G. Weilgart Patten: soils-phosphorus content, soils-nitrogen content, soil biology;

- Cynthia L. Kahrmann: soil management-Maine, plant nutrients, vegetables-nutrition, vegetables-composition;

- Harvey Bolton: farm management, soil microbiology;

- Walter Allen Goldstein: agriculture, agronomy; and

- Stephan Dabbert: agricultural economics.

The authors were unsuccessful in identifying much of the organic agricultural research conducted at Michigan State University and mentioned in Masterson's letter. There was insufficient detail about the research in the letter, and searches of the Michigan State catalog by LC subject headings and keywords gave only one possible match: Patricia S. Michalak's 1984 MS thesis, titled Comparative Analysis of Collembola Associated with Organic and Conventional Ecosystems, which had "organic farming" as the fourth of five subject headings. Possibly, the research Masterson described went uncompleted or undocumented in writing.

There were two research projects, one at the University of Nebraska and the other at Washington State University, that were not identified clearly enough to warrant inclusion in Table 3 . The putative identity of a Nebraska MS thesis is Organic Farming in Eastern Nebraska by Eileen A. Cunningham, completed in July 1982; its LC subject heading is "organic farming-Nebraska." The unidentified Washington State University MS thesis may be the one titled Long-term Tillage and Rotation Effects on Soil Biomass, Carbon, and Nitrogen by David Michael Granatstein, completed in 1986; its LC subject headings are "tillage," "soil microbiology," and "soil biochemistry." 
In all cases, these were appropriate subject headings, given the thesis content. However, it often was not apparent from the title or the catalog record that the research had any relationship to organic agriculture, making these documents unavailable to researchers, and unavailable to support the USDA's claim of conducting organic research, and disseminating the results, in the early 1980s. Avoidance of the term "organic," whether intentional or not, likely made the identification of information difficult for interested parties.

\section{WHAT THE DOCUMENTS REVEAL}

Taken chronologically, the documents listed in Tables 1 to 3 provide insight into the roller-coaster relationships among the Congress, the USDA, and organic producers, and into the changes that occurred in politics and agricultural research in the 1970s and 1980s. Throughout the congressional hearings published during the period 1970-1974 (Table 1), the common understanding was that synthetic pesticides and fertilizers were necessary to continue U.S. agriculture's successful level of production. One example of this belief is found in a 1969 hearing's written testimony. Mary K. Farinholt stated:

Chemical pesticides are here to stay. An increasing population will require more food from a static or shrinking farm acreage. Besides the sheer quantity of food U.S. consumers demand, the quality they expect includes diversity and lack of blemish, infestation and decay. Furthermore, the big capital invested in the big business of farming today will not tolerate gambling on possible crop loss, when a preventive is at hand. Without chemical pesticides, according to a National Academy of Sciences subcommittee, many fruits and vegetables would disappear from the market, and many other crops would grow so meagerly they would be marketable only as rare luxuries. ${ }^{39}$

In a similar vein, Sen. Robert J. Dole (R-Kan.) commented, during hearings on water pollution in 1971,

Recently concern has arisen over the long-term effects of pesticides, herbicides, fungicides, and fertilizers used in agriculture. This concern is proper and should not be taken lightly. At the same time, however, it should be remembered that all of these chemicals 
are tools for the farmer. They are important tools that have been developed to increase both the productivity and efficiency of agriculture. They are in large measure responsible for the greatness of American agriculture today. Without these chemicals, American farmers could not offset the tremendous drain of manpower away from rural areas of our country. They would not be able to meet the ever-increasing demand for food generated by our rising population. ${ }^{40}$

Both excerpts illustrate the web of concerns that surround U.S. agriculture, regarding not only pollution, but also limited arable land, limited manpower, and food quantity and quality. The testimony of most USDA officials and many growers, during the hearings listed in both Tables 1 and 2, echoed the importance of agrichemicals and continued research into their development and applications. There was at that time the sense that, without pesticides and synthetic fertilizers, U.S. agriculture would no longer support the needs of the citizenry and of the world. In 1977 Russell Schwandt, President of the Minnesota Agri-Growth Council, testified,

There are those who say we need an alternative to pesticides. . . . we need to research new and better and safer pesticides, because without pesticides we are facing economic collapse and mass starvation throughout the world, no question about it. Every farmer, such as I with my gray hair ... have tried the organic farming. Organic farming is good if you have a few vegetables, or a flower box. If you are going to try to feed 8 billion people, it's a bunch of nonsense. ${ }^{41}$

However, there was no objective evidence that these catastrophic failures would occur. There was no research into organic farming that documented reduced yields that could then be extrapolated into "mass starvation." There were, however, examples of larger-scale, successful organic farmers, with yields and per-acre incomes comparable with those of conventional growers. In 1977, farmer Howard Beeman testified about his successful diversified organic farming operation in California, growing tomatoes, rice, alfalfa, wheat, and oat hay on 560 acres. ${ }^{42}$ Other success stories included Paul Keene of Walnut Acres, one of the early organic growers in the country; ${ }^{43}$ Earl Lawrence, whose family ran a successful 325 -acre farm in Virginia; ${ }^{44}$ and the Midwestern organic corn farmers documented by Barry Commoner's research group 
at Washington University in St. Louis, in the study titled "Economic Performance and Energy Intensiveness on Organic and Conventional Farms in the Corn Belt: A Preliminary Comparison." 45 Some USDA officials looked beyond the accepted pattern of pesticide usage. One administrator, Roy L. Lovvorn of the Cooperative State Research Service, discussed his concerns in this 1971 exchange with Rep. Robert H. Michel (R-Ill.): 46

Mr. Michel: Getting into the whole question of environmental quality, with the increasing restrictions on the uses of pesticides, are we giving enough attention to developing nonchemical ways of pest control? And, just how far can we go in limiting pesticide usage in agriculture before we start running into really serious production problems? What kind of safety margin are we operating on here? ... After years of thinking in terms of the declining need for any kind of production research, are we going to be faced with the necessity for a major shift in our thinking about our basic ability to feed ourselves? Just how serious is this situation?

Dr. Lovvorn: In our view adequate attention is not being given to developing nonchemical ways of pest control ... All of the elements exist today to suggest that the current and anticipated demands for environmental quality, the general urbanization and industrialization needs, and the foreign and domestic population's food and fiber requirements will all serve to sharply increase the total array of restrictions and demands on the system.

The size of the problem is appreciated when we reflect on the fact that with few exceptions all plant culture systems in this country were designed with reliance on chemical pest control, or at least with recognition that within a relatively short period of time it could be brought into use ...

There are extensive opportunities in the area of developing nonchemical ways of pest control, and we do have some research in this area underway at this time. Many of the more basic and fundamental areas that would most efficiently yield the knowledge necessary for full exploitation of nonchemical ways of pest control are not now receiving adequate attention ...

Organic farming provided methods for nonchemical pest control. And it is certainly true that, in 1971, the USDA was not paying attention. 
However, as congressional interest in organic agriculture began to escalate in the mid-1970s, USDA officials found attention focused upon the agency's research priorities. In 1975, Rep. George E. Brown, Jr. queried Dr. T. W. Edminster, Administrator of the ARS: ${ }^{47}$

Has not the thrust of your research program over the years tended to favor the development of chemical pesticides, fertilizers and so forth, at the expense of the organic approach and at the expense of programs such as integrated pest management, which I think there is an obligation to pursue?

Mr. Edminster provided written material that indicated that the ARS devoted "approximately 30 percent of our effort . . . on the basic . . . ecology, and physiology of pests. Another 40 percent [of their effort] is focused on nonchemical methods of control ...," 48 with the emphasis on insect pests. This figure does not address, specifically, weed problems-and therefore alternatives to chemical herbicides-or other pathogens of plants and animals, such as fungi and nematodes, which were controlled or eradicated, at that time, by broad-spectrum fungicides and nematicides. Of the remaining $30 \%$ of USDA-ARS effort, Edminster mentioned,

Roughly 21 percent . . . is devoted to research on the development of safe and effective pesticide use patterns. Much of this research is conducted cooperatively with private industry. The remaining 9 percent of the effort is based on determining what happens to pesticides that are applied to plants, farm animals, and to soil and water. ${ }^{49}$

With at least 30\% of ARS' effort in 1975 expended towards chemical pesticide testing, agrichemical companies (the "private industry" to which Edminster refers) might be expected to take a rather dim view of any widespread adoption of organic research programs by USDA. Congressional interest also included the collection of faculty attitudes about organic farming, and a survey of the coursework and extension-related information available at U.S. land grant institutions, USDA's traditional partners in agricultural research and development. Sen. James Abourezk (D-S. Dak.) canvassed these institutions by letter in 1977, and the responses by university officials were primarily indifference or hostility to organic farming, as opposed to organic gardening. Several correspondents commented on organic agriculture as another "food 
faddism" of American society. ${ }^{50}$ Despite the official positions of most USDA and university officials, the testimonies and written statements from some legislators, researchers, and many growers expressed a desire for the USDA to conduct research into organic production methods (Table 2). In general, the inflexibility and slow response of the USDA bureaucracy, especially the ARS, is clear in a review of these hearings during the 1970s. Edminister presented an interesting potential explanation for the nature of ARS' response, in a comment that may list the agency's priorities. In his 1975 testimony, he stated:

Information that we use in priority setting in the Agency flows from a large number of valued sources, both within and outside the Agency. The Congress, agribusinesses, producers, marketing firms, commodity groups, action agencies, and many others consistently request research information and recommend to us their needs ... The determination of research priorities is coordinated with action agencies, with other research agencies and the private sector. ${ }^{51}$

Regardless of any prioritization, the ARS did not address congressional interest in organic agriculture, and it appears that the views of organic producers were lower in importance. This hearing marked the beginning of a series of missed opportunities and delays, on the part of various branches of the USDA, to follow the suggestions of Congress and its constituents, and to clearly define and increase its research into organic farming. A classic exchange that illustrates this point occurred in 1982 between Rep. Jim Weaver (D-Ore.) and Dr. Terry Kinney, Administrator of the USDA-ARS: 52

Mr. Weaver: I agree completely that if it becomes a fight of one word versus another-chemical versus organic-nobody is going to be helped. We simply have to develop techniques that work.

I still have a feeling that there are elements out there that would suppress this [organic] information. I can assure you that the people I know in organic farming have very little means to suppress information on chemical farming, but the chemical industry can exert some of its influence on organic farming.

I would like to ask one final question of Dr. Kinney. We know that we have one person part-time on the staff of the USDA for answering inquiries into organic farming techniques [Organic Farming 
Coordinator Dr. I. Garth Youngberg.]. How many specialists do you have on your staff in the chemical field?

Dr. Kinney: Scientists who are working specifically in ...

$M r$. Weaver: In the chemical field-insecticides, pesticides, et cetera.

Dr. Kinney: I would say a couple hundred.

Mr. Weaver: A couple hundred?

Dr. Kinney: Yes.

Mr. Weaver: I do not think I have to say anything more.

The mention of the Organic Farming Coordinator introduces the next phase (1980-1985) in the history of organic farming legislation and USDA response. In 1980, there was a thaw in the USDA's attitude towards organic agriculture, when Secretary of Agriculture Bob Berglund assembled the study team that produced the Report and Recommendations on Organic Farming (Table 2) that developed the definition of organic farming discussed previously. Dr. Youngberg, a political scientist, served in the role of Organic Farming Coordinator as part of the Policy and Coordination Staff, USDA-Science and Education, not part of ARS. During his brief tenure (1980-1983), Youngberg reported to Congress on his observations of continued and increasing interest in organic agriculture and alluded to some of the difficulties associated with his position in this 1982 conversation with Rep. Weaver: ${ }^{53}$

Mr. Weaver: What kinds of responses have there been to the organic farming report, published in 1980?

Dr. Youngberg: [T] here has been an outstanding response. We probably have distributed somewhere in the neighborhood of 38,000 to 39,000 copies of the report to date. . . .

These were distributed primarily, if not totally, as a result of individual requests as opposed to a mass mailing distribution.

$M r$. Weaver: So there is a great deal of interest out there in this, is there not?

Dr. Youngberg: That would be my judgment, yes. This is based upon impressions, not a systematic study, but the requests both for information and the report have come from a rather broad spectrum of farmers. ... 
Mr. Weaver: What has the U.S. Department of Agriculture done to meet this? Have you been provided with additional staff? Have you been able to broaden your information services ... ?

Dr. Youngberg: I have been attempting primarily to respond to these by myself, but I am supported by what is called the Organic Farming Coordinating Committee, which consists of 10 scientists and other technical specialists. These are people who have other jobs-full-time responsibilities in the Department-but they were anxious to be a part of a follow-up activity.

Youngberg himself worked first full time, then half time in his role as Coordinator; he had other duties in the Science and Education branch. ${ }^{54}$ And despite the interest generated by the 1980 USDA Report, there were no additional funds budgeted or requested specifically for organic agricultural research during the period 1980-1985.55 Youngberg's efforts, and those of supportive USDA and university researchers, were encouraging. For example, Warren Sahs, in a 1982 exchange with Rep. Weaver, mentioned how his fellow researchers at the University of Nebraska began to recognize the need for a more thorough examination of organic agriculture:

$M r$. Weaver: The second question is, Is [sic] there general consensus on this [organic farming] among the faculty in your school and any other school you happen to know about, or is it controversial?

Mr. Sahs: That is a good question. In 1975, I would say it was about 75 percent of people who were not interested in this approach, and 25 percent were. Now I would say it is 90 percent in favor of alternate cropping systems or organic farming, and maybe 10 percent diehards who are still pretty well hung up on the fertilizer bag.

Mr. Weaver: That is very interesting.

Mr. Sahs: This was not by direct leadership. It is leadership, but I mean it was not a dictum from the front office at Ag Hall. In other words, this is a gradual switching of opinions by each individual scientist as you went down the last 7 years. ${ }^{56}$

A change in the Executive Branch, when President Reagan succeeded Carter, led to the replacement of Secretary Berglund by John R. 
Block and momentum dissipated. By 1983, Youngberg was let go by USDA; he became executive director of the Institute for Alternative Agriculture. ${ }^{57}$ However, Youngberg's appointment leads to a larger question: why was a political scientist, and not an agronomist or other life scientist with biologically based knowledge of agricultural practices and problems, hired as the Organic Farming Coordinator? The question does not impugn Youngberg's abilities or commitment, but is relevant because the Coordinator was to "[develop] long-range plans for research and educational programs in biological farming," duties perhaps better assigned to an agricultural researcher with field experience. ${ }^{58}$ This hiring choice suggested that ARS viewed organic farming questions as less than "real science." In this decision, the USDA leadership chose to look at these research questions more from a sociological/economic viewpoint.

During 1982-1983, the USDA and Congress would collide again, as Rep. Jim Weaver proposed the Organic Farming Act of 1982 in February of that year (Table 2). The bill had two objectives: the initiation of organic research projects by USDA at several pilot farms throughout the country and the utilization of a network of volunteers, knowledgeable in organic farming, to staff the nation's Cooperative Extension offices and to provide information to interested growers. The USDA declined to support the legislation, citing budgetary and personnel limitations, and the legislation did not proceed. ${ }^{59}$ John R. Block, the Secretary of Agriculture, stated in his letter declining support, that the "Department has several ongoing programs that relate to the needs of organic systems." 60 Several members of Congress, in their written dissent to the legislation, supported Block and stated,

At the current time, USDA is in the process of conducting a comprehensive search of written materials from the public and private sectors concerning organic agriculture. This literature search will take approximately one year. Once these materials are collected and reviewed, it would be proper to go forward in some form in regard to research on less chemically intensive agriculture methods. ${ }^{61}$

This specific "search of written materials" took several forms. Charles N. Bebee and Jayne T. MacLean, at the NAL, already had an ongoing series of Quick Bibliographies that drew information from Agricola entries during this period. ${ }^{62}$ These bibliographies, while not intended to be comprehensive, were collected from a wide range of publication types 
and were international in scope. In 1981, J. W. Schwartz, a soil scientist with the USDA-Science and Education Administration, completed $A$ Bibliography for Small and Organic Farmers 1920-78 (Table 2). ${ }^{63}$ The bibliography consisted of research publications organized into 19 topics, and in many respects addressed the "comprehensive search" mentioned a year later by the Congressmen quoted elsewhere in this article. It is unknown what or who prompted the preparation and publication of Schwartz's bibliography. The USDA's Current Research Information Service (CRIS) compiled a more rigorous and complicated search entitled Organic-Related Farming Systems Research FY82: A Directory of USDA and State Projects in CRIS ${ }^{64}$ (Table 2) in 1985. Three retired professors of agricultural sciences, from Iowa State University, reviewed this literature about USDA and land grant research projects at the USDA's request; they published a report summarizing their review, Conventional and Organic-Related Farming Systems Research: An Assessment of USDA and State Research Projects, ${ }^{65}$ in 1986 (Table 3). The latter report is important for two reasons. First, its findings supported, from 1986 through 1989, the USDA's claims that the Department was active in organic agricultural research and that USDA shared this research information with interested farmers through its Cooperative Extension Service. As a result, there is no evidence that organic agricultural research received any specific appropriations. ${ }^{66}$ But the appropriation decisions were not well founded, because secondly, the 1986 analysis of Schaller, Thompson, and Smith (Table 3) is confounded by the lack of a clearly defined and accepted definition for organic farming. Because the USDA's definition allowed for the use of synthetic pesticides, some research projects received the label of "organic-related" in the Schaller et al. study; current researchers would consider these projects to be related to "integrated pest management." 67

From 1985 until 1989, there is little legislative activity pertaining to organic agriculture, based on a review of CIS indexing and NAL's Quick Bibliographies and of legislation identified by using related terms and phrases. In 1988, a House Subcommittee held a hearing to explore "low-input farming," but not organic farming in the sense discussed here. ${ }^{68}$ The following year, a Senate subcommittee examined the role of conservation tillage in sustainable agriculture. ${ }^{69}$ However, the "zero" or "no-till" methods relied heavily on synthetic pesticide applications for weed and pest control and so do not fit with the practices of most organic producers. The Congress had other concerns about U.S. agriculture from 1985 to 1989 , including the high rate of family farm 
failures (the "Farm Crisis"), an ongoing drought, and international trade concerns.

This discussion ends before the legislative proposals of the 1990 Farm Bill, specifically the Organic Foods Production Act, which created the NOP and the NOSB. A review of the pertinent legislative and selected USDA-sponsored documents, published between 1970 and 1989 , leads to the following conclusions:

- There was a lack of a consistent, acceptable definition for "organic" farming during these years. Prior to the 1980 definition created by the USDA Study Team, "organic" meant different things to politicians, to USDA researchers and administrators, and to both conventional and organic producers. This confusion probably hampered serious research efforts. Even after the promulgation of the USDA definition, organic producers and consumers noted discrepancies between the definition and their actual practices and beliefs. The lack of clear communication carried over into the establishment of the NOP and the NOSB and may have played a role in the decade-long delay in the implementation of the National Organic Standards.

- The documentation demonstrates USDA's slow and inflexible response to Congress and those among its farming constituents interested in organic agricultural methods. With the exception of a brief period under Secretary Bob Berglund (1980-1983), the congressional hearings and legislation indicate congressional interest-in response to constituent interest-colliding with USDA's unwillingness to commit significant financial or personnel resources to organic research and the dissemination of information.

- The USDA claimed to support research into organic methods, particularly during the 1980s. An official tabulation and review of projects, as indexed by the Current Research Information Service (CRIS), is confounded by the USDA's definition of "organic farming"; there were projects categorized as "organic" with which many organic producers and consumers would disagree. However, the USDA did support a number of graduate-level research projects. Ironically, these were difficult to identify, either because controlled vocabulary did not reflect the use of popular terminology, or because there was reticence to use the term "organic" in the legitimate scientific arena. These missing pieces of evidence sustain USDA's claim of support for some, albeit limited, organic agricultural research. 
- Taken as a whole, the documents reflect the building momentum of interest-politically, popularly, and in the research arena-in organic production, which would erupt in 1990 with the passage of the Organic Foods Production Act. The findings illustrate the relationship between a bureaucracy-the USDA-and its constituents, American growers and, by extension, organic consumers. Despite missed opportunities and many delays, the persistence of citizens, scientists, and government officials led to recognition, at the Federal level, for the organic farmer and consumer. The economic power of the organic consumer eventually led to the development of the NOP, and the knowledge base of organic producers supported the creation of the NOSB.

Currently, the USDA mostly avoids the term "organic" in discussions of research efforts. But the Department has developed additional research and outreach programs useful to organic farmers and consumers, including Sustainable Agricultural Research and Education (SARE), Appropriate Technology Transfer for Rural Areas (ATTRA), and the Alternative Farming Systems Information Center (AFSIC), part of NAL. The AFSIC, with funding from the USDA-NOP and SARE, launched "Organic Agriculture Information Access," a digitized collection of "historic [pre-1942] USDA publications related to organic agriculture." 70 And at the end of 2005, Secretary Johanns appointed the first executive director for the NOSB, an action long overdue. According to Sen. Patrick Leahy, Congress "repeatedly directed USDA to hire an Executive Director ... . and provided increased funds to the National Organic Program for that purpose." 71 But the USDA and the organic movement still continue an uneasy relationship. For example, in 2004, under Secretary Ann Veneman's watch, USDA issued directives on organic certification without first presenting these to the NOSB, as required by law. ${ }^{72}$

Organic agriculture in the United States has progressed over the last three decades, certainly in its economic impact and its popularity with consumers, and also in the recognition of its place as a legitimate research venue. Organic farmer Howard Beeman, Jr. hopefully had many of his concerns, voiced in 1977, addressed by legislative and USDA activities over the intervening years: ${ }^{73}$

But representing the organic farming movement has really been a joke so far ... no one's picked it up at the Federal level. Congress 
people have kicked it around a little bit; but we're making no progress. In California I felt the biggest obstacle to progress were individuals in the mainstream agriculture who felt there was such a threat from organic farming that they wanted to quash it immediately ...

But I do think that Government could give organic farming some recognition. They could get together and define certain terms. There's laws on the books now to enforce it. The market in the organic food business is shady at best, I feel. But you can't enforce those laws without some sort of definitions, or without some people starting some activities in court ... I'm asking now that someone pick that up as their cause, to see if we can't straighten out this small part of agriculture. It's probably not going to dominate, the other methods are much more attractive. But for the people that do choose that route, the road could be made a lot smoother.

\section{NOTES}

1. Office of the Press Secretary, "President Nominates Governor Mike Johanns as Secretary of Agriculture." (December 2, 2004) available at http://www.whitehouse. gov/news/releases/2004/12/20041202-6.html (accessed February 11, 2006).

2. Deb Riechmann, "Bush Names Nebraska Governor as Secretary of Agriculture." The Associated Press State \& Local Wire (December 2, 2004) Online. Lexis-Nexis Academic Universe; Jake Thompson, "Johanns Making Rounds of Senators." Omaha World-Herald (December 8, 2004): 1A; Patrick Leahy, "Statement of Senator Patrick Leahy. Confirmation Hearing of Governor Michael Johanns." (January 6, 2005) available at http://leahy.senate.gov/press/200501/010605b.html (accessed February 11, 2006).

3. Jake Thompson, "Johanns: Hearing Went Well. The Senate Ag Committee Unanimously Backs the Nebraskan's Nomination as Ag Secretary, Sending His Selection to the Floor." Omaha World-Herald (January 7, 2005): 1A.

4. Senate Committee on Agriculture, Nutrition, and Forestry, Nomination of Hon. Michael Johanns, to be Secretary of the U.S. Department of Agriculture. S. Hrg. 109-012, 109th Cong., 1st sess. (January 6, 2005) available at http://frwebgate.access. gpo.gov/cgi-bin/getdoc.cgi?dbname=109_senate_hearings\&docid=97781. wais (accessed February 11, 2006).

5. Organic Trade Association, "Sec. Johann's Replies to Sen. Leahy." (2005) available at http://www.ota.com/pp/usregulatory/Johanns-Leahy.html (accessed February 11, 2006).

6. U.S. Department of Agriculture, Economic Research Service, Data, Organic Production, 1992-2003. (2005) available at http://ers.usda.gov/Data/Organic/ (accessed February 19, 2006).

7. Michael D. Jawson, "Adding OOMPH to Organic Farming." Agricultural Research 50, no. 2 (2002): 2. 
8. World Trade Organization/United Nations International Trade Center, cited in Catherine Greene and Amy Kremen, U.S. Organic Farming in 2000-2001: Adoption of Certified Systems. Economic Research Service, U.S. Department of Agriculture. (2003): 2, available at http://ers.usda.gov/publications/aib780/aib780.pdf (accessed February 11, 2006).

9. U.S. Department of Agriculture, Economic Research Service, Briefing Room, Organic Farming and Marketing: Maps and Images Gallery. (2005), available at http:// ers.usda.gov/Briefing/Organic/Gallery/productintro.htm (accessed February 19, 2006).

10. Stephanie D. Smith, “A Natural Phenomenon.” Money 31, no. 12 (2002): 56.

11. Jawson (2002): 2.

12. Organic Consumers Association, "New Secretary of Agribusiness, Mike Johanns, Expresses Tepid Support for Booming Organic Sector." (2005) available at http://www. organicconsumers.org/organic/johanns012505.cfm (accessed February 11, 2006).

13. Organic Trade Association, "Organic Trade Association Looks Forward to Working with New Ag Secretary." (2005) available at http://www.ota.com/news/ press/162.html (accessed February 11, 2006).

14. Mark Lipson, Searching for the "O-Word": Analyzing the USDA Current Research Information System for Pertinence to Organic Farming. Santa Cruz, CA: Organic Farming Research Foundation (1997); James F. Parr, "USDA Research on Organic Farming: Better Late Than Never." American Journal of Alternative Agriculture 18 , no.3 (2003): 171-172.

15. Charles N. Bebee, Quick Bibliography Series, Organic Farming or Gardening 1969-1976: 154 Citations. Beltsville, MD: Science and Education Administration, U.S. Department of Agriculture (1976); Charles N. Bebee, Quick Bibliography Series, Organic Farming and Gardening, 1969-1978: 200 Citations. Beltsville, MD: Science and Education Administration, U.S. Department of Agriculture (1979); Jane Potter Gates, Tracing the Evolution of Organic/Sustainable Agriculture: A Selected and Annotated Bibliography, Beltsville, MD: National Agricultural Library, U.S. Department of Agriculture (1988); Jayne T. MacLean, Quick Bibliography Series, Organic Farming and Gardening-Revision, 1970-1982: 300 Citations. Beltsville, MD: National Agricultural Library, U.S. Department of Agriculture (1982); Jayne T. MacLean, Quick Bibliography Series, Organic Farming and Gardening-Revision, 1970-1983: 274 Citations. Beltsville, MD: National Agricultural Library, U.S. Department of Agriculture (1983); Jayne T. MacLean, Quick Bibliography Series, Organic Farming and Gardening, 1979-1984: 137 Citations. Beltsville, MD: National Agricultural Library, U.S. Department of Agriculture (1984); Jayne T. MacLean, Quick Bibliography Series, Organic Farming and Gardening, 1979-1984: 221 Citations. Beltsville, MD: National Agricultural Library, U.S. Department of Agriculture (1985); Jayne T. MacLean, Quick Bibliography Series, Organic Farming and Gardening, 1981-85: 253 Citations. Beltsville, MD: National Agricultural Library, U.S. Department of Agriculture (1986); Jayne T. MacLean, Quick Bibliography Series, Organic Farming and Gardening, 1983-1986: 258 Citations. Beltsville, MD: National Agricultural Library, U.S. Department of Agriculture (1987); Jayne T. MacLean, Quick Bibliography Series, Organic, Low-Input or Sustainable Agriculture, 1984-1987: 249 Citations. Beltsville, MD: National Agricultural Library, U.S. Department of Agriculture (1988); Jayne T. MacLean, Quick Bibliography Series, Organic, Low-Input or Sustainable Agriculture, January 1985-September 1988: 233 Citations. Beltsville, MD: National Agricultural Library, U.S. Department of Agriculture (1989a); Jayne T. MacLean, Quick Bibliography Series, Organic, Low-Input or Sustainable Agriculture, June 1986-March 1989: 
306 Citations. Beltsville, MD: National Agricultural Library, U.S. Department of Agriculture (1989b); Jayne T. MacLean, Quick Bibliography Series, Sustainable or Alternative Agriculture, January 1982-December 1989: 321 Citations. Beltsville, MD: National Agricultural Library, U.S. Department of Agriculture (1990); Jayne T. MacLean, Quick Bibliography Series, Sustainable or Alternative Agriculture, January 1988-January 1991: 338 Citations. Beltsville, MD: National Agricultural Library, U.S. Department of Agriculture (1991); Karl Schneider, Quick Bibliography Series, Alternative Farming Systems-Economic Aspects, 1970-1986. Beltsville, MD: National Agricultural Library, U.S. Department of Agriculture (1987); Karl Schneider, Quick Bibliography Series, Alternative Farming System-Economic Aspects, 1979-May 1988. Beltsville, MD: National Agricultural Library, U.S. Department of Agriculture (1988).

16. "Eco-Agriculture: A Review of Its History and Philosophy." Biological Agriculture and Horticulture 1 (1983): 181-210. Also see A. M. Scofield, "Organic Farming-The Origin of the Name." Biological Agriculture and Horticulture 4 (1986): 1-5.

17. Available at http://www.ams.usda.gov/nop/Consumers/brochure.html (accessed February 11, 2006).

18. The Congressional Information Service, Cumulative Index for 1970-1974. Washington, DC: Congressional Information Service (1975). Other alternative indexing terms utilized in the literature search were unproductive, namely "agricultural pollution," "alternative farming," "biological research," "botany," "energy conservation," "Environmental Defense Fund," "farm income," "fertilizer," "pesticides," "plant disease," "soil conservation service," "soil management," "sustainable farming," "vegetables," "Vegetable Growers Association of America," and "water pollution."

19. Senate Subcommittee on Migratory Labor, Committee on Labor and Public Welfare, Migrant and Seasonal Farmworker Powerlessness, Pt. 6-C, Hearings on Pesticides and the Farmworker. 91 st Cong., 1st and 2nd sess. (September 30, 1969): 3910.

20. Everett J. Dietrick, in Testimony Before the Senate Subcommittee on Agricultural Research and General Legislation, Committee on Agriculture and Forestry, Federal Environmental Pesticide Control Act, Pt. 1, Hearings on S. 232, S. 272, S. 660, and S. 745. (March 23-26, 1971): 152.

21. Migrant and Seasonal Farmworker Powerlessness, Pt. 6-C (September 30, 1969): 3910. Also see Senate Subcommittee on Agricultural Credit and Rural Electrification, Committee on Agriculture and Forestry, Fertilizer Supply, Demand, and Prices, Part 2. 93rd Cong., 2nd sess. (March 8, 1974): 337-338.

22. House Subcommittee on Science, Research, and Technology and Subcommittee on Domestic and International Scientific Planning and Analysis, Committee on Science and Technology, Agricultural Research and Development, Special Oversight Hearings, Part II (Committee Serial No. 51). 94th Cong., 1st sess. (September 23-25 and 30, October 1-2, 24-25, 1975).

23. Ibid., 110-112. The first example of the term's use was in an exchange between T. W. Edminster, USDA-ARS and Rep. George E. Brown, Jr.

24. United States Department of Agriculture, USDA Study Team on Organic Farming, Report and Recommendations on Organic Farming (1980): 9.

25. Warren Sahs, Assistant Director of the Nebraska Agricultural Experiment Station, during testimony in support of the Organic Farming Act of 1982, on June 10, 1982, before the House Subcommittee on Forests, Family Farms, and Energy, Committee on Agriculture, Hearing on H. R. 5618 (Committee Serial No. 97-SSS). 97th Cong., 2nd sess. (1982): 51. Also see: Terry Meisenbach, ed., Alternative Farming Task Force Report, August 1983. Lincoln, NE: Institute of Agriculture and Natural 
Resources, Agricultural Experiment Station, and Cooperative Extension Service, University of Nebraska (1983).

26. Sahs, Organic Farming Act of 1982, Hearing on H. R. 5618 (Committee Serial No. 97-SSS). (1982): 51.

27. Ray Wolf, ed., Organic Farming: Yesterday's and Tomorrow's Agriculture. Emmaus, PA: Rodale Press (1977): 2.

28. For example, in House Subcommittee on Family Farms, Rural Development, and Special Studies, Committee on Agriculture, Obstacles to Strengthening Family Farm System (Committee Serial No. 95-BB). 95th Cong., 1st sess. (September 30 and October 15, 28-29, 1977) see: statement of Francis Angier, National Organic Farmers Association, 138-141; statement of Howard Prussack, farmer, 164-167; exchange between Rep. Richard Nolan and Gloria and Pedro Castex, New Life Farm, 525-527; excerpts from statement of Howard Beeman, farmer, 531-532, 535-537. During the hearing before the Senate Subcommittee on Administrative Practice and Procedure, Committee on the Judiciary, Priorities in Agricultural Research of the U.S. Department of Agriculture, Part 1. 95th Cong., 1st sess. (October 19-20, 1977) see: testimony of Ardell Anderson, Living Farms, Tracy, MN, 3-7. In Senate Subcommittee on Nutrition, Committee on Agriculture, Nutrition, and Forestry, Nutrition Labeling and Information, Part IV, Hearing on S. 1651. 96th Cong., 2nd sess. (April 1, 1980) see: statement of Paul Keene, Walnut Acres, 22-24, 95-106, and "The Walnut Acres Story," 107-118.

29. Nicolas Lampkin, Organic Farming, Ipswich, UK: Farming Press Books (1990); Philip Conford, The Origins of the Organic Movement. Edinburgh: Floris Books (2001).

30. House Subcommittee on Department Operations, Research and Foreign Agriculture, Committee on Agriculture, Agricultural Productivity Act of 1983 (Committee Serial No. 98-50), Hearing on H. R. 2714. 98th Cong., 1st sess. (August 3, 1983): $63,67$.

31. Ibid., 67-68.

32. Ibid., 68.

33. 2005 edition, available at http://agclass.nal.usda.gov/agt/agt.shtml (accessed February 11, 2006).

34. House Subcommittee on Department Operations, Research, and Foreign Agriculture, Committee on Agriculture, Sustainable Agricultural Systems (Committee Serial No. 97-PPP). 97th Cong., 2nd sess. (April 16, 22, and 27, 1982): 288-293.

35. Available at http://authorities.loc.gov (accessed February 11, 2006).

36. Ibid.

37. MacLean (1988): 10.

38. Sustainable Agricultural Systems (Committee Serial No. 97-PPP). (April 16, 22 , and 27, 1982): 288-293.

39. Senate Subcommittee on Migratory Labor, Committee on Labor and Public Welfare, Migrant and Seasonal Farmworker Powerlessness, Pt. 6-B, Hearings on Pesticides and the Farmworker. 91st Cong., 1st and 2nd sess. (September 29, 1969): 3491.

40. Senate Subcommittee on Air and Water Pollution, Committee on Public Works, Water Pollution Control Legislation, Agricultural Runoff, Part 6 (Committee Serial No. 92-H11), Hearings on S. 75, S. 192, S. 280, S. 281, S. 523, S. 601, S. 679, S. 927, S. 1011, S. 1012, S. 1013, S. 1014, S. 1015, and S. 1017. 92nd Cong., 1st sess. (April 2, 1971): 2518 . 
41. Obstacles to Strengthening Family Farm System (Committee Serial No. 95-BB). (September 30 and October 15, 28-29, 1977): 249-250.

42. Ibid., 531-532.

43. Statement of Paul Keene in Priorities in Agricultural Research of the U.S. Department of Agriculture, Part 1. (October 19-20, 1977): 22-24 and 95-106 and "The Walnut Acres Story," Nutrition Labeling and Information, Part IV, Hearing on S. 1651. (April 1, 1980): 107-118.

44. Organic Farming Act of 1982, Hearing on H. R. 5618 (Committee Serial No. 97-SSS). (1982): 43-46.

45. Klepper, Robert, William Lockeretz, Barry Commoner, Michael Gertler, Sarah Frost, Daniel O'Leary, and Roger Blobaum, "Economic Performance and Energy Intensiveness on Organic and Conventional Farms in the Corn Belt: A Preliminary Comparison." American Journal of Agricultural Economics 59, no.1 (Feb. 1977): 1-12. This article is also found in its entirety in Priorities in Agricultural Research of the U.S. Department of Agriculture, Part 1. (October 19-20, 1977): 147-158.

46. House Subcommittee of the Committee on Appropriations, Agriculture-Environmental and Consumer Protection Appropriations for 1972, Part 2, Hearings, Department of Agriculture. 92nd Cong., 1st sess. (March 10, 15, and 16, 1971): 584-585.

47. Agricultural Research and Development, Special Oversight Hearings, Part II (Committee Serial No. 51). (September 23-25 and 30, October 1-2, 24-25, 1975): 111.

48. Ibid., 113.

49. Ibid.

50. Senate Subcommittee on Administrative Practice and Procedure, Committee on the Judiciary, Priorities in Agricultural Research of the U.S. Department of Agriculture-Appendix, Part 2. 95th Cong., 1st sess. (1978).

51. Agricultural Research and Development, Special Oversight Hearings, Pt. II (Committee Serial No. 51). (September 23-25 and 30, October 1-2, 24-25, 1975): $70-71$.

52. The Organic Farming Act (Committee Serial No. 97-SSS), Hearing on H. R. 5618. (1982): 21.

53. Ibid., 14-15.

54. Ibid., 15.

55. Sustainable Agricultural Systems (Committee Serial No. 97-PPP). (April 16, 22 , and 27, 1982): 120.

56. Organic Farming Act of 1982 (Committee Serial No. 97-SSS). (1982): 54. Another supportive university researcher was Dr. J. Patrick Madden, an agricultural economist at The Pennsylvania State University. For his testimonies, see: Priorities in Agricultural Research of the U.S. Department of Agriculture, Part 1. (October 19-20, 1977): 16; House Subcommittee on Department Operations, Research, and Foreign Agriculture, Committee on Agriculture, General Farm Bill of 1985 (Research, Extension, Teaching, and Export Programs) (Committee Serial No. 99-5, Part 4). 99th Cong., 1st sess. (March 27 and April 4, 1985): 356-357.

57. Agricultural Productivity Act of 1983 (Committee Serial No. 98-50), Hearing on H. R. 2714. (August 3, 1983): 56.

58. Sustainable Agricultural Systems (Committee Serial No. 97-PPP). (April 16, 22 , and 27, 1982): 117.

59. United States House of Representatives, Organic Farming Act of 1982. H. Rpt. 97-733, 97th Cong., 2nd sess. (August 12, 1982): 11-13 and 16.

60. Ibid., 13. 
61. Ibid., 16.

62. Bebee (1976, 1979); MacLean (1982, 1983, 1984, 1985, 1986, 1987, 1988, 1989a,b, 1990, 1991).

63. J. W. Schwartz, A Bibliography for Small and Organic Farmers 1920-78. Beltsville, MD: Science and Education Administration, U.S. Department of Agriculture (1981).

64. Organic-Related Farming Systems Research FY82: A Directory of USDA and State Projects in CRIS. Beltsville, MD: Current Research Information Service (1985).

65. F. W. Schaller, F. W., H. E. Thompson, and C. M. Smith, Conventional and Organic-Related Farming Systems Research: An Assessment of USDA and State Research Projects. Ames, IA: Agricultural and Home Economics Experiment Station, Iowa State University (1986).

66. Senate Subcommittee on Agricultural Research and General Legislation, Committee on Agriculture, Nutrition, and Forestry, Agricultural Productivity Act of 1983, Hearing on S. 1128. S. Hrg. 98-1018, 98th Cong., 2nd sess. (June 14, 1984): 17.

67. Ibid., 16.

68. House Subcommittee of the Committee on Government Operations, Environmental and Economic Benefits of Low-Input Farming. 100th Cong., 2nd sess. (April $28,1988)$.

69. Senate Subcommittee on Agricultural Research and General Legislation, Committee on Agriculture, Nutrition, and Forestry, Conservation Tillage Technology Research, Implications for a Sustainable Agriculture, On Recent Research on the "Zero" or "No-Till" Methods of Conservation Tillage. 101st Cong., 1st sess. (March 15, 1989).

70. Available at http://www.hti.umich.edu/n/nal or http://www.nal.usda.gov/afsic/ (accessed February 27, 2006).

71. Available at http://www.organicconsumers.org/organic/johanns012505.cfm (accessed February 11, 2006). Also see Greg Bowman, "National Organics Board Welcomes Six New Members," The New Farm (December 8, 2005) available at http:// www.newfarm.org/news/2005/1205/nosb_print.shtml (accessed February 20, 2006).

72. "Organic Label Should Get More Respect," Lincoln (NE) Journal Star (June 7, 2004), 4B; http://www.organicconsumers.org/organic/usdaantibioticdirective.pdf (accessed February 12, 2006); http://www.organicconsumers.org/organic/feeddirective. pdf (accessed June 6, 2005); http://www.organicconsumers.org/organic/usdapesticid edirective.pdf (accessed February 11, 2006).

73. Obstacles to Strengthening Family Farm System (Committee Serial No. 95-BB). (September 30 and October 15, 28-29, 1977): 536-537.

\section{REFERENCES}

Alternative Farming Systems Information Center. "Organic Agriculture Information Access.” Retrieved February 27, 2006 from http://www.hti.umich.edu/nal or http:// www.nal.usda.gov/afsic/.

American Marketing Service. "National Organic Program.” Retrieved February 11, 2006 from http://www.ams.usda.gov/nop/Consumers/brochure.html.

American Society of Agronomy, Crop Science Society of America, and Soil Science Society of America. Organic Farming: Current Technology and Its Role in a 
Sustainable Agriculture, ASA Special Publication No. 46. Madison, WI: The Societies, 1984.

Bebee, Charles N. Quick Bibliography Series, Organic Farming and Gardening 1969-1976: 154 Citations. Beltsville, MD: Science and Education Administration, U.S. Department of Agriculture, 1976.

Bebee, Charles N. Quick Bibliography Series, Organic Farming and Gardening, 1969-1978: 200 Citations. Beltsville, MD: Science and Education Administration, U.S. Department of Agriculture, 1979.

Bolton, Harvey. Soil Microbial Biomass and Selected Soil Enzyme Activities on an Alternatively and Conventionally Managed Farm. MS Thesis. Pullman, WA: Washington State University, 1983.

Bowman, Greg. "National Organics Board Welcomes Six New Members." The New Farm December 8, 2005. Retrieved February 20, 2006 from http://www.newfarm. org/news/2005/1205/nosb_print.shtml.

Broder, Michael W. Changes in Nitrogen Metabolising Microorganisms Under Different Tillage Systems in Western Nebraska. MS Thesis. Lincoln, NE: University of Nebraska, 1981.

Conford, Philip. The Origins of the Organic Movement. Edinburgh: Floris Books, 2001.

Council for Agricultural Science and Technology. Utilization of Animal Manures and Sewage Sludges in Food and Fiber Production, Report No. 41. Washington, DC: CAST, 1975.

Council for Agricultural Science and Technology. Organic and Conventional Farming Compared, Report No. 84. Washington, DC: CAST, 1980.

Cunningham, Eileen A. Organic Farming in Eastern Nebraska. MS Thesis. Lincoln, NE: University of Nebraska, 1982.

Current Research Information Service. Organic-Related Farming Systems Research FY1982: A Directory of USDA and State Projects in CRIS. Beltsville, MD: Current Research Information Service, U.S. Department of Agriculture, 1985.

Dabbert, Stephan. A Dynamic Simulation Model of the Transition from Conventional to Organic Farming. MS Thesis. University Park, PA: The Pennsylvania State University, 1986.

Economic Research Service. "Briefing Room, Organic Farming and Marketing: Maps and Images Gallery.” 2005. Retrieved February 19, 2006 from http://ers.usda.gov/ Briefing/Organic/Gallery/productintro.htm.

Economic Research Service. "Data, Organic Production, 1992-2003.” 2005. Retrieved February 19, 2006 from http://ers.usda.gov/Data/Organic/.

Foster, Gary Stanford. The Kansas Organic Producers: Alternative Agriculture as a Social Movement. PhD dissertation. Manhattan, KS: Kansas State University, 1981.

Gates, Jane Potter. Tracing the Evolution of Organic/Sustainable Agriculture: A Selected and Annotated Bibliography. Beltsville, MD: National Agricultural Library, U.S. Department of Agriculture, 1988.

Goldstein, Walter Allen. Alternative Crops, Rotations, and Management Systems for the Palouse (Compost, Wheat, Washington). PhD Dissertation. Pullman, WA: Washington State University, 1986.

Granatstein, David Michael. Long-Term Tillage and Rotation Effects on Soil Biomass, Carbon, and Nitrogen. MS Thesis. Pullman, WA: Washington State University, 1986. 
Greene, Catherine and Amy Kremen. "U.S. Organic Farming in 2000-2001: Adoption of Certified Systems.” Economic Research Service, U.S. Department of Agriculture. 2003. Retrieved February 11, 2006 from http://ers.usda.gov/publications/ aib780/aib780.pdf.

House Subcommittee of the Committee on Appropriations. Agriculture-Environmental and Consumer Protection Appropriations for 1972, Part 2, Hearings, Department of Agriculture. 92nd Cong., 1st sess. March 10, 15, and 16, 1971.

House Subcommittee of the Committee on Appropriations. Agriculture-Environmental and Consumer Protection Appropriations for 1974, Part 8, Miscellaneous. 93rd Cong., 1st sess. March 26, 1973.

House Subcommittee of the Committee on Government Operations. Environmental and Economic Benefits of Low-Input Farming. 100th Cong., 2nd sess. April 28, 1988.

House Subcommittee on Conservation, Credit, and Rural Development, Committee on Agriculture. Miscellaneous Conservation [Committee Serial No. 98-13], Hearings on Soil and Water Conservation Concerns and Issues, and on H. R. 568, 2714, 2928, 3457, 3903, and 3906. 98th Cong., 1st sess. May 4 and Sept. 20, 1983.

House Subcommittee on Department Operations, Research, and Foreign Agriculture, Committee on Agriculture. Sustainable Agricultural Systems (Committee Serial No. 97-PPP). 97th Cong., 2nd sess, April 16, 22, and 27, 1982.

House Subcommittee on Department Operations, Research, and Foreign Agriculture, Committee on Agriculture. Agricultural Productivity Act of 1983 (Committee Serial No. 98-50), Hearing on H. R. 2714. 98th Cong., 1st sess. August 3, 1983.

House Subcommittee on Department Operations, Research, and Foreign Agriculture, Committee on Agriculture. General Farm Bill of 1985 (Research, Extension, Teaching, and Export Programs) (Committee Serial No. 99-5, Part 4). 99th Cong., 1st sess. March 27 and April 4, 1985.

House Subcommittee on Family Farms, Rural Development, and Special Studies, Committee on Agriculture. Obstacles to Strengthening Family Farm System (Committee Serial No. 95-BB). 95th Cong., 1st sess. September 30 and October 15, 28-29, 1977.

House Subcommittee on Forests, Family Farms, and Energy, Committee on Agriculture. Organic Farming Act of 1982, Hearing on H. R. 5618 (Committee Serial No. 97-SSS). 97th Cong., 2nd sess. June 10, 1982.

House Subcommittee on Science, Research, and Technology and Subcommittee on Domestic and International Scientific Planning and Analysis, Committee on Science and Technology. Agricultural Research and Development, Special Oversight Hearings, Part II (Committee Serial No. 51). 94th Cong., 1st sess. September 23-25 and 30, October 1-2, 24-25, 1975.

Jawson, Michael D. "Adding OOMPH to Organic Farming." Agricultural Research 50, no.2 (2002): 2.

Kahrmann, Cynthia L. Nutritional Quality Factors of Vegetables Grown under Organic and Conventional Soil Management Systems. MS Thesis. Orono, ME: University of Maine, 1982.

Klepper, Robert, William Lockeretz, Barry Commoner, Michael Gertler, Sarah Frost,Daniel O'Leary, and Roger Blobaum. "Economic Performance and Energy 
Intensiveness on Organic and Conventional Farms in the Corn Belt: A Preliminary Comparison." American Journal of Agricultural Economics 59, no. 1 (Feb. 1977): $1-12$.

Kraten, Steven L. A Preliminary Examination of the Economic Performance and Energy Intensiveness of Organic and Conventional Small Grain Farms in the Northwest. MA Thesis. Pullman, WA: Washington State University, 1979.

Lampkin, Nicolas. Organic Farming. Ipswich, UK: Farming Press Books, 1990.

Leahy, Patrick. "Statement of Senator Patrick Leahy. Confirmation Hearing of Governor Michael Johanns." January 6, 2005. Retrieved February 11, 2006 from http:// leahy.senate.gov/press/200501/010605b.html.

Library of Congress. "Authority Headings." Retrieved February 11, 2006 from http:// authorities.loc.gov.

Lipson, Mark. Searching for the "O-Word": Analyzing the USDA Current Research Information System for Pertinence to Organic Farming. Santa Cruz, CA: Organic Farming Research Foundation, 1997.

MacLean, Jayne T. Quick Bibliography Series, Organic Farming and Gardening-Revision, 1970-1982: 300 Citations. Beltsville, MD: National Agricultural Library, U.S. Department of Agriculture, 1982.

MacLean, Jayne T. Quick Bibliography Series, Organic Farming and Gardening-Revision, 1970-1983: 274 Citations. Beltsville, MD: National Agricultural Library, U.S. Department of Agriculture, 1983.

MacLean, Jayne T. Quick Bibliography Series, Organic Farming and Gardening, 1979-1984: 137 Citations. Beltsville, MD: National Agricultural Library, U.S. Department of Agriculture, 1984.

MacLean, Jayne T. Quick Bibliography Series, Organic Farming and Gardening, 1979-1984: 221 Citations. Beltsville, MD: National Agricultural Library, U.S. Department of Agriculture, 1985.

MacLean, Jayne T. Quick Bibliography Series, Organic Farming and Gardening, 1981-85: 253 Citations. Beltsville, MD: National Agricultural Library, U.S. Department of Agriculture, 1986.

MacLean, Jayne T. Quick Bibliography Series, Organic Farming and Gardening, 1983-86: 258 Citations. Beltsville, MD: National Agricultural Library, U.S. Department of Agriculture, 1987.

MacLean, Jayne T. Quick Bibliography Series, Organic, Low-Input or Sustainable Agriculture, 1984-1987: 249 Citations. Beltsville, MD: National Agricultural Library, U.S. Department of Agriculture, 1988.

MacLean, Jayne T. Quick Bibliography Series, Organic, Low-Input or Sustainable Agriculture, January 1985-September 1988: 233 Citations. Beltsville, MD: National Agricultural Library, U.S. Department of Agriculture, 1989a.

MacLean, Jayne T. Quick Bibliography Series, Organic, Low-Input or Sustainable Agriculture, June 1986-March 1989: 306 Citations. Beltsville, MD: National Agricultural Library, U.S. Department of Agriculture, 1989 b.

MacLean, Jayne T. Quick Bibliography Series, Sustainable or Alternative Agriculture, January 1982-December 1989: 321 Citations. Beltsville, MD: National Agricultural Library, U.S. Department of Agriculture, 1990.

MacLean, Jayne T. Quick Bibliography Series, Sustainable or Alternative Agriculture, January 1988-January 1991: 338 Citations. Beltsville, MD: National Agricultural Library, U.S. Department of Agriculture, 1991. 
Meisenbach, Terry, ed. Alternative Farming Task Force Report, August 1983. Lincoln, NE: Institute of Agriculture and Natural Resources, Agricultural Experiment Station and Cooperative Extension Service, University of Nebraska, 1983.

Merrill, Margaret C. "Eco-Agriculture: A Review of Its History and Philosophy." Biological Agriculture and Horticulture 1 (1983): 181-210.

Michalak, Patricia S. Comparative Analysis of Collembola Associated with Organic and Conventional Ecosystems. MS Thesis. Lansing, MI: Michigan State University, 1984.

National Agricultural Library. "Thesaurus." 2005. Retrieved February 11, 2006 from http://agclass.nal.usda.gov/agt/agt.shtml.

Office of the Press Secretary. "President Nominates Governor Mike Johanns as Secretary of Agriculture.” December 2, 2004. Retrieved February 11, 2006 from http:// www.whitehouse.gov/news/releases/2004/12/20041202-6.html.

Organic Consumers Association. "New Secretary of Agribusiness, Mike Johanns, Expresses Tepid Support for Booming Organic Sector." 2005. Retrieved February 11, 2006 from http://www.organicconsumers.org/organic/johanns012505.cfm.

“Organic Label Should Get More Respect.” Lincoln (NE) Journal Star June 7, 2004, 4B.

Organic Trade Association. "Organic Trade Association Looks Forward to Working with New Ag Secretary." 2005. Retrieved February 11, 2006 from http://www. ota.com/news/press/162.html.

Organic Trade Association. "Sec. Johann's Replies to Sen. Leahy." 2005. Retrieved February 11, 2006 from http://www.ota.com/pp/usregulatory/Johanns-Leahy.html.

Parr, James. "USDA Research on Organic Farming: Better Late Than Never." American Journal of Alternative Agriculture 18, no.3 (2003): 171-172.

Riechmann, Deb. "Bush Names Nebraska Governor as Secretary of Agriculture." The Associated Press State \& Local Wire December 2, 2004: Online. Lexis-Nexis Academic Universe.

Schaller, F. W., H. E. Thompson, and C. M. Smith. Conventional and Organic-Related Farming Systems Research: An Assessment of USDA and State Research Projects. Ames, IA: Agricultural and Home Economics Experiment Station, Iowa State University, 1986.

Schneider, Karl. Quick Bibliography Series, Alternative Farming Systems-Economic Aspects, 1970-1986. Beltsville, MD: National Agricultural Library, U.S. Department of Agriculture, 1987.

Schneider, Karl. Quick Bibliography Series, Alternative Farming Systems-Economic Aspects, 1979-May 1988. Beltsville, MD: National Agricultural Library, U.S. Department of Agriculture, 1988.

Schwartz, J. W. A Bibliography for Small and Organic Farmers 1920-78. Beltsville, MD: Science and Education Administration, U.S. Department of Agriculture, 1981.

Scofield, A. M. "Organic Farming-The Origin of the Name." Biological Agriculture and Horticulture 4 (1986): 1-5.

Senate Committee on Agriculture, Nutrition, and Forestry. "Nomination of Hon. Michael Johanns, to be Secretary of the U.S. Department of Agriculture." S. Hrg. 109-012, 109th Cong., 1st sess. January 6, 2005. Retrieved February 11, 2006 from http://frwebgate.access.gpo.gov/cgi-bin/getdoc.cgi?dbname=109_senate_hearings \&docid=97781. wais. 
Senate Subcommittee on Administrative Practice and Procedure, Committee on the Judiciary. Priorities in Agricultural Research of the U.S. Department of Agriculture, Part 1. 95th Cong., 1st sess. October 19-20, 1977.

Senate Subcommittee on Administrative Practice and Procedure, Committee on the Judiciary. Priorities in Agricultural Research of the U.S. Department of Agriculture-Appendix, Part 2. 95th Cong., 1st sess. 1978.

Senate Subcommittee on Agricultural Credit and Rural Electrification, Committee on Agriculture and Forestry. Fertilizer Supply, Demand, and Prices, Part 2. 93rd Cong., 2nd sess. March 8, 1974.

Senate Subcommittee on Agricultural Research and General Legislation, Committee on Agriculture and Forestry. Federal Environmental Pesticide Control Act, Pt. 1, Hearings on S. 232, S. 272, S. 660, and S. 745. March 23-26, 1971.

Senate Subcommittee on Agricultural Research and General Legislation, Committee on Agriculture and Forestry. Federal Environmental Pesticide Control Act, Pt. II, Hearings on H. R. 10729. March 7-8, 1972.

Senate Subcommittee on Agricultural Research and General Legislation, Committee on Agriculture, Nutrition, and Forestry. Agricultural Productivity Act of 1983, Hearing on S. 1128. S. Hrg. 98-1018, 98th Cong., 2nd sess. June 14, 1984.

Senate Subcommittee on Agricultural Research and General Legislation, Committee on Agriculture, Nutrition, and Forestry. Conservation Tillage Technology Research, Implications for a Sustainable Agriculture, On Recent Research on the Zero or "No-Till" Methods of Conservation Tillage. 101st Cong., 1st sess. March 15, 1989.

Senate Subcommittee on Air and Water Pollution, Committee on Public Works. Water Pollution Control Legislation, Agricultural Runoff, Part 6 (Committee Serial No. 92-H11), Hearings on S.75, S. 192, S. 280, S. 281, S. 523, S. 601, S. 679, S. 927, S. 1011, S. 1012, S. 1013, S. 1014, S. 1015, and S. 1017.92nd Cong., 1st sess. April 2, 1971.

Senate Subcommittee on Executive Reorganization and Government Research, Committee on Government Operations. Chemicals and the Future of Man. 92nd Cong., 1st sess. April 6 and 7, 1971.

Senate Subcommittee on Migratory Labor, Committee on Labor and Public Welfare. Migrant and Seasonal Farmworker Powerlessness, Pt. 6-A, Hearings on Pesticides and the Farmworker. 91st Cong., 1st and 2nd sess. August 1, 1969.

Senate Subcommittee on Migratory Labor, Committee on Labor and Public Welfare. Migrant and Seasonal Farmworker Powerlessness, Pt. 6-B, Hearings on Pesticides and the Farmworker. 91st Cong., 1st and 2nd sess. September 29, 1969.

Senate Subcommittee on Migratory Labor, Committee on Labor and Public Welfare. Migrant and Seasonal Farmworker Powerlessness, Pt. 6-C, Hearings on Pesticides and the Farmworker. 91st Cong., 1st and 2nd sess. September 30, 1969.

Senate Subcommittee on Nutrition, Committee on Agriculture, Nutrition, and Forestry. Nutrition Labeling and Information, Part IV, Hearing on S. 1651.96th Cong., 2nd sess. April 1, 1980.

Smith, Stephanie. “A Natural Phenomenon.” Money 31, no. 12 (2002): 56.

The Congressional Information Service. Cumulative Index for 1970-1974. Washington, DC: Congressional Information Service, 1975.

Thompson, Jake. "Johanns Making Rounds of Senators." Omaha World-Herald, December 8, 2004, $1 \mathrm{~A}$. 
Thompson, Jake, "Johanns: Hearing Went Well. The Senate Ag Committee Unanimously Backs the Nebraskan's Nomination as Ag Secretary, Sending His Nomination to the Floor." Omaha World-Herald, January 7, 2005, 1 A.

United States Congress. Public Law 95-113, Food and Agriculture Act of 1977, Title XIV (National Agricultural Research, Extension, and Teaching Policy Act of 1977), Subtitle F (Small Farm Research and Extension), Section 1440 (Small Farm Research and Extension Programs). 91 Stat. 1005. 95th Cong. September 29, 1977.

United States Congress. Public Law 95-113, Food and Agriculture Act of 1977, Title XIV (National Agricultural Research, Extension, and Teaching Policy Act of 1977), Subtitle J (Studies), Section 1461 (Organic Farming Study). 91 Stat. 1016. 95th Cong. September 29, 1977.

United States Congress. Public Law 97-98, Agriculture and Food Act of 1981, Title XIV (National Agricultural Research, Extension, and Teaching Policy Act Amendments of 1981), Section 1402 (Findings), subpart (10) (D) (v). 95 Stat. 1295. 97th Cong. December 22, 1981.

United States Congress. Public Law 99-198, Food Security Act of 1985, Title XIV (Agricultural Research, Extension, and Teaching), Subtitle A (General Provisions), Section 1402 (Findings). 99 Stat. 1543. 99th Cong. December 23, 1985.

United States Congress. Public Law 99-198, Food Security Act of 1985, Title XIV (Agricultural Research, Extension, and Teaching), Subtitle C (Agricultural Productivity Research), Section 1464 (Information Study). 99 Stat. 1564. 99th Cong. December 23, 1985.

United States Department of Agriculture. Improving Soils with Organic Wastes. Washington, DC: U.S. Department of Agriculture, 1978.

United States Department of Agriculture. Report and Recommendations on Organic Farming. Washington, DC: U.S. Department of Agriculture, 1980.

United States House of Representatives. Organic Farming Act of 1982. H. Rpt. 97-733. 97th Cong., 2nd sess. August 12, 1982.

United States House of Representatives. Improving the Productivity of American Farms. H. Rpt. 98-587. 98th Cong., 1st sess. December 9, 1983.

United States House of Representatives. Directing the Secretary of Agriculture to Take Certain Actions to Improve the Productivity of American Farmers, and for Other Purposes. H. Rpt. 99-126. 99th Cong., 1st sess. May 15, 1985.

United States Senate. S. 2485, Innovative Farming Act of 1982. 97th Cong., 2nd sess. May 5, 1982.

Weilgart Patten, Andrea G. Comparison of Nitrogen and Phosphorus Flows on an Organic and Conventional Farm. M. S. Thesis. Pullman: Washington State University, 1982.

Wolf, Ray, ed. Organic Farming: Yesterday's and Tomorrow's Agriculture. Emmaus, PA: Rodale Press, 1977.

Received: 03/01/06

Revised: 08/09/06

Accepted: 08/18/06

doi:10.1300/J108v08n01_06 